\title{
$\mathrm{C}|\mathrm{E}| \mathrm{D}|\mathrm{L}| \mathrm{A} \mid \mathrm{S}$
}

Centro de Estudios

Distributivos, Laborales y Sociales

Maestría en Economía

Universidad Nacional de La Plata

\section{Unemployment Duration and Labor Mobility in Argentina: A Socioeconomic-Based Pre- and Post- Crisis Analysis}

Gustavo Javier Canavire-Bacarreza y Luís Fernando Lima Soria

Documento de Trabajo Nro. 54

Julio, 2007 


\title{
UNEMPLOYMENT DURATION AND LABOR MOBILITY IN ARGENTINA: A SOCIOECONOMIC-BASED PRE- AND POST- CRISIS ANALYSIS
}

\author{
Gustavo Javier Canavire-Bacarreza \\ Department of Economics \\ Andrew Young School of Policy Studies \\ Georgia State University \\ ecocjcbx@langate.gsu.edu
}

\author{
Luís Fernando Lima Soria \\ CEDLAS \\ Facultad de Ciencias Económicas \\ Universidad Nacional de La Plata \\ luislima@,depeco.econo.unlp.edu.ar
}

\begin{abstract}
This paper evaluates the unemployment duration and labor mobility using data from the household surveys provided by the National Statistical office (INDEC) for the period 1998 to 2005. The paper aims to understand and explain the evolution and main determinants of labor mobility and unemployment duration, two of the main problems that labor markets present. Unemployment duration is studied in terms of welfare and its determinants by applying stochastic dominance and econometric techniques. Labor mobility is analyzed using conditional multinomial probit techniques in order to evaluate its evolution, the impact of a crisis and the recovery period, that Argentina faced over the period 1998-2005. We found that there was deterioration in welfare measured by unemployment duration especially during the crisis period. We found that human capital played a key role in the unemployment duration and labour mobility. Unemployment duration is higher for people with higher educational levels, which shows that less educated people have lower reservations wages; similar result was found for females and males. The labour mobility results show that more educated people enter easier to formal labor markets which changes during the crisis when their probability of entering to formal labor market reduces; this would suggest that more educated people tend to adjust their wages and push out of the market less educated people. The labour mobility patterns do not reflect inflexibility in labour markets. We conclude that the apparent duality formal and informal - in the Argentinean labour market which seems to reflect differences in access to productive resources (buman capital) outside labour market is the one that determines the integration into labour markets and later labour mobility of a big part of labour force.
\end{abstract}

Keywords: Unemployment duration, labour mobility, stochastic dominance, count models, hazard models. JEL Classification: J62, J64, C41

\footnotetext{
${ }^{1}$ We appreciate the comments and suggestions from Anna Baranchuck and the participants at the seminar at Universidad Nacional de La Plata. All remaining errors are our own. The opinions expressed in this document do not necessarily represent the opinions of the institutions where the authors are affiliated Additional comments will be highly appreciated.
} 


\section{INTRODUCTION}

One of the main problems economy faces is labor market distortions, among which two of the most important are labor mobility and unemployment. They have direct effects on product, inequality, over development, and growth itself. Generally, the way economy develops directly affects the increasing number of unemployed people, unemployment duration and labour mobility.

Over the last 20 years Argentina showed high levels of economic growth with a sudden stop due to one of the biggest economic crises in its history, which had negative effects on the welfare of the country and the region. This crisis period had direct effects on the Argentinean labor market, resulting in increased unemployment, increased job-searching time, and labor mobility pushing workers towards the informal sectors of the economy characterized by lower wages and lack of benefits.

In fact, the increase of unemployment duration and precarious employment during the crisis had direct effects on labour mobility growth shifting employees towards the informal sectors of the economy and decreasing the quality of employment in the country, which had harmful effects on welfare of the society.

The increase of unemployment duration could have been related to factors such as government protective programs and changes in employment laws; but it is also correlated to the socioeconomic characteristics of the people.

Empirical literature on unemployment duration and labour mobility shows two trends to analyze their determinants and their evolution. We can split this into two groups according to the type of information available: either using information at macro level or household surveys. This document uses the "Permanent Household Survey" (PHS) carried out by the National Institute of Statistics and Census in Argentina (INDEC) from 1998 to $2005^{2}$ given their availability and flexibility.

The objective of this study is to characterize the levels, the evolution and the determinants of unemployment duration and labour mobility in Argentina before, during and after the crisis the country faced between 1999 and 2001. To reach this aim, we use stochastic dominance techniques applied to unemployment duration and econometric modeling to analyze both unemployment duration and labour mobility.

The second section of this document presents a brief review of literature on unemployment duration and labour mobility as well as empiric evidence for the specific Argentinean case. The third section presents a descriptive analysis of unemployment in Argentina, and in particular of the main variables related to employment duration and labour mobility. The fourth section analyzes unemployment duration and its determinants applying stochastic dominance, count models and hazard models. The fifth section presents evaluation of labour mobility through the use of probability and mobility models, and finally the sixth section presents conclusions of the document.

\footnotetext{
2 PHS surveys from 1998 to 2002 taken only from October of each year. In 2003 taken only from May and continuous PHS surveys from 2003 to 2005 taken only from the 2 nd semester of each year. This period is included because it is necessary to carry out a detailed analysis before, during and after the Argentinean crisis.
} 


\section{WHERE DO WE STAND? A BRIEF REVIEW OF LITERATURE}

Labor dynamics requires an evaluation of labour mobility and unemployment duration due to its harmful effects on the economy itself and social welfare given that it allows the redistribution of welfare between workers, especially during periods of crisis. The implementation of social programs to prevent a deterioration of the labour markets require an extensive analysis of this two phenomenon.

Most labor market studies analyze unemployment duration and labor mobility using two different information sources household surveys (at micro level) and national accounts (at macro level). Each one has different benefits; macro data give information about the whole population, but do not give any information about individuals, and it is mainly used to evaluate regional and demographic events. Included in this review are the works of van den Berg (1994), van Ours (1996), van den Berg and van den Klaauw (2001), and van den Berg and van Ours (2002).

On the other hand, household data have detailed sociodemographic information for individuals and households sociodemographic characteristics. However, similar to macro level information, they also have some disadvantages. For example, in panel surveys follow up time is generally short; and in punctual surveys there is no individual follow up. This kind of analysis has been applied to Colombia (Castellar and Uribe (2003)), Chile (Pertiraca (2005)) and Bolivia (Canavire and Landa (2006)). Both found that the most important determinants of unemployment duration are sex, income, educational attainment, and several other regional factors.

Perhaps the most ambiguous argument is related to education. Rõõm (2002) and Steiger et. al. (2001) assert that higher educational levels would reduce unemployment duration. Kupetz (2005) affirms that, given the reserve salary of less educated people, their unemployment duration would be lower and labor mobility would be higher.

For Argentina, Galiani and Hopenhayn (2001) show evidence that the exit of unemployment (understand as leaving unemployment) has a negative relationship with worker age, increases for men, and is highly dependent on unemployment duration. This document analyzes the pre-crisis period 1989-1998.

Regarding labor mobility in Argentina there are some documents that analyze this topic basically using economic and sociological points of view. Kessler and Espinoza (2003) present an extensive literature review and highlight studies of Germani (1963) and Beccaria (1978). Germani describes labor status of parents and children, and their mobility between manual and non-manual occupations. Using information for 1960 he concludes that even if these occupations do not have high structural mobility they still present movements inside them.

Beccaria, using information for the same year, evaluates the occupational environment of parents and children and complements Germani's findings stating that despite the mobility along manual and non-manual occupations there is still a decrease in low quality activities in both cases. Beccaria y Maurizio (2003) analyzes labour mobility and unemployment duration between 1998 and 1999, recovering an existent relationship between the latter and the informal market. They establish that, even if there is an outflow from employment to unemployment, the informal sector was unable to absorb those 
unemployed; however, an employment and unemployment effect is always present during periods of expansion and recession.

In general, these studies present a clear distinction between intergenerational labour mobility and labour mobility by sector. On one hand, intergenerational labour mobility usually tries to evaluate the father's socioeconomic status and analyze the quality of life of the children in the future, as an approximation to social mobility of individuals. Jorrat (1997) using data from 1982 observes that although there is little mobility between manual and no-manual occupations, the latter still shows less growth.

Recently, Jorrat (2005) presented an analysis on intergenerational mobility of parents and children between 2003 and 2004, suggesting that "apparently the 2001 crisis would have "blurred" certain mobility guidelines (de facto) historically attributed to the social stratification of Argentina". On the other hand, labour mobility by sector evaluates the labor movement of each individual who, because of an exogenous cause, has to change many times to a different situation, either better or worse. This document, given its thematic, analyzes labour mobility from this point of view.

The government, thorough the Ministry of Labor, Employment and Social Security ${ }^{3}$ (2005), corroborates that labour mobility among individuals who worked in private companies between 1996 and 2004 decreased during 2001 and 2002, only to increase again between 2003 and 2004, a period of economic recovery, for two reasons. First, many employees who left during the crisis returned to work since the labour market could absorb the unemployed; and second, a lot of people that couldn't find a new job entered the private sector or started working for the first time implying that there was a lag on the abortion of labour force entrants. Moreover, this study show that both young people and adults had to face greater problems when looking for employment, therefore age was not see as problem; and yet, young women with low levels of education were the most affected by unemployment.

According to Cortés and Groisman (2004), the problem of labour mobility and its relationship with economic growth and with the formal and informal sectors was mainly caused by international migration to the stable country of the nineties, greatly stopping internal migration. Foreign employees started jobs with long working hours and low wages.

An individual will want to work or keep his job if he gets paid at least his reservation wage. However, in the presence of crisis and distortions in the labour markets, many people would look to find a job as quickly as possible without caring if this is formal or informal and even with a salary below the established minimum wage or even his reservation wage. Gutierrez (2004) concludes that economic recession in Argentina generated great unemployment risk and other characteristics, such as to be an under paid worker with a low educational level.

Gasparini (2005) shows that in Argentina during 1992, 1996 and 2001 the percentage of informal work increased specially in female population. Moreover, salaries were lower as a result of the growing inequalities seen in the nineties and the reduction of labour protection in Argentina.

In 2002 a plan called "Plan Jefes y Jefas de Hogar Desocupados en Argentina" was implemented under the safety nets idea. One of the main objectives of this plan was to

\footnotetext{
${ }^{3}$ Document: "Job, occupation and employment. Previous experience, collective negotiation and income".
} 
reduce unemployment duration and more specifically to stimulate employment generation. However, it had a structural problem; it was a sort of "unemployment insurance" for the informal sector, without time limits and with certain requirements. Its implementation was questioned since recession was over ${ }^{4}$.

In short, if we analyze labour mobility in Argentina from 1998 to 2005, a period characterized by economic crisis and recovery, people made different decisions according to their sociodemographic characteristics. The need to find a job was confronted with the possibility of not finding one that remunerates according to the educational level or the family situation. For this reason it is necessary to analyze unemployment duration as part of labour mobility, because depending on the characteristics of each individual, the time of search for formal or informal employment varies.

\section{EMPLOYMENT CHARACTERISTICS IN ARGENTINA}

The International Labour Organization (ILO) and the United Nations (UN) established basic definitions to measure labour force, occupation, and unemployment in household surveys. According to the standard definitions, unemployed population (UP) is one that belongs to labour force and did not work during the reference period or established their own business in a determined period of time.

According to ILO (2004) $)^{5}$ the average unemployment rate in Latin America was $11.1 \%$ in 2003, which means that 11 out of 100 people belonging to the labour force were unemployed. Argentina is in second place above the region's average, with an unemployment rate of $17.3 \%$ (See figure 1).

Figure 1

\section{Latin America: Urban unemployment rate, 2003}

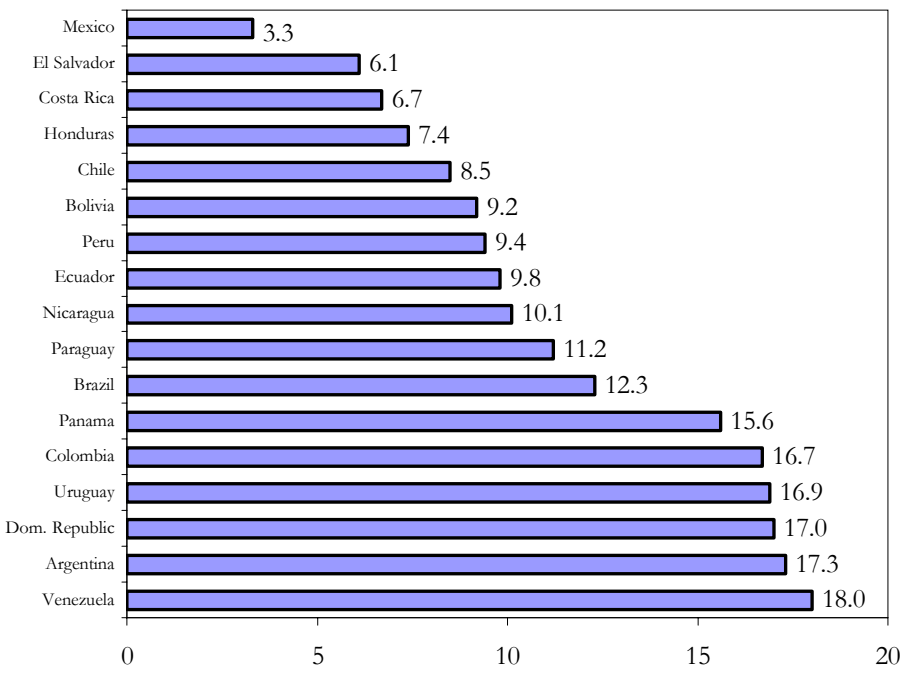

Source: ILO 2004

Perhaps the unemployment rate is the most important and widely used indicator to analyze the evolution of any economy. In the Argentinean case we can observe a clear tendency over the period of 1998-2004. In the year 1998 12.5\% of the labour force was

\footnotetext{
${ }^{4}$ For more details see Vinocur y Halperin (2004) and Golbert (2004).

5 Some of the unemployment rates presented by ILO include the rate of hidden unemployment which takes into account people who were considered temporarily inactive and sub-employed population
} 
unemployed, while during the crisis period it increased due to the slowdown of the economy and the outflow of capital; more specifically in the years of deep crisis - in 2001 and 2002 - the unemployment rate increased in almost 6 points compared to the previous periods showing a clear deterioration in the economy and labour market. During the period of 2003-2004 we observe a slight recovery of unemployment which is still not enough to compensate the increase that happened in the crisis. (See Table 1)

Labour markets in developing countries, especially in Latin America ${ }^{6}$ show high informality level; even if Argentina is below the region average it is still a problem that the society has to face. In average, over the period 1998 to $200443.2 \%$ of the occupied people were working on informal sectors. The levels of informality did not presented high variability over the period of crisis which led to think that reservation wages did not fully adjusted generating higher levels of unemployment.

When we observe the unemployment duration, we found a clear increase on its average not attributable to frictional unemployment. In the year 1998 the average unemployment duration for people over 15 years was 6.1 months, which had been growing until 2002 and kept the same behaviour over the period 2003-2005. This, along with the unemployment levels show that there is a slow adjustment on the economy and could be an indicator that the public policy programs that were applied have not been successful.

The most vulnerable groups in crisis have been the older ones. During the period 2001 and 2002 the increase of unemployment duration has been higher in this groups compared to the younger ones and remained over the period 2003 - 2004. This is attributable to the change in the productive structure and the technology assimilation that Argentina had to face over this period which caused an isolation of less technology adaptive groups.

Unemployment duration is higher for females in all age cohorts. This is supported by empirical evidence that females in general have higher reservation wages than men; especially in segments of the population with lower income therefore their job searching time is longer.

Educational levels show that unemployment duration is higher for more educated people; moreover during the crisis period this was the group that faced a higher increase in unemployment duration. This is due to the fact that it is more difficult for better educated people to adjust their reservation salaries, but also it is more difficult to enter to informal sectors (See Table 2).

\section{UNEMPLOYMENT DURATION AND ITS DETERMINANTS ${ }^{7}$}

The appropriate methodology to study unemployment duration is the analysis of the classic job search theory, which takes elements from the statistical theory of sequential decision making, information theory and the economics of uncertainty and builds its theoretical foundations in a dynamic programming context.

Unemployment duration, from the econometric point of view, is based on transition analysis which takes into account the transition between two states, unemployment and employment and the amount of time between one state to the other; many times assuming

\footnotetext{
${ }^{6}$ The informality rate for Latin America is $55 \%$. Argentina is below this average and in position 13 .

7 This section uses as reference the document by Canavire y Landa (2006) "Unemployment duration in Bolivian urban areas: an analysis of the effects of levels of education and socioeconomic characteristics".
} 
that the latter takes place at the moment when the information is obtained. In this sense, there are two main relations that search theory takes into account: the probability of exiting one state (unemployment) and the duration in this next state (search).

It is important to notice that, given the nature of the unemployment duration variable, in a particular moment there will be individuals who would leave unemployment while others would remain in it. Martín (1995) goes back to the origins of the theory up to the so called discrete time sequential search model ${ }^{8}$, including also the optimal sample size. Heckman and Singer (1984) argue that the characterization of decisions in continuous time is more realistic due to the absence of a natural time unit in which a decision is made.

Lancaster (1990) suggests the interaction between theory and applied methods, and establishes preference in the usage of hazard models for the analysis of unemployment duration in continuous time; however he also suggests applying count models when the available data is in discrete time.

We use intensively the information available in the household survey in Argentina and present the results of three different ways to analyze the evolution of unemployment duration. First, we use stochastic dominance to analyze the evolution of unemployment duration, second, we analyze the determinants of unemployment duration using count models and, finally, we apply hazard models to confront and confirm the results obtained before. To reach this aim we calculate unemployment duration through the existent panel and through the question: how long have you been unemployed?

\section{a. Stochastic Dominance in unemployment duration}

One alternative to analyze unemployment duration in terms of welfare is applying stochastic dominance techniques. Two studies of this kind are known. First, Yañez (2004) presented a way to analyze the social function taking unemployment duration into account and using generalized Lorenz curves. These curves are used compare welfare in two situations, or in this case comparing two different unemployment duration spells.

Second, Canavire and Landa (2006) apply stochastic dominance curves to analyze the distribution of unemployment duration in Bolivia from 1999 to 2003. These curves show an improvement in welfare measured by unemployment duration between 2000 and 2003 in relation to 1999. Also, 2003 shows an improvement in welfare in relation to 2000, 2001 and 2002 .

The Argentinean case is presented under the same approach. First, however, we present a short theoretical explanation of the methodology applied.

To analyze whether there was improvement in social welfare, it is necessary to use the Atkinson's Theorem (1970) ${ }^{9}$ which, in summary, says:

\footnotetext{
${ }^{8}$ Job Search Theory defines discrete time as a standard duration measurement, for example: months, years, etc.

${ }^{9}$ From Mitnik (1999).
} 
a) If the measures of income ${ }^{10}$ are equal and Lorenz curves do not intersect, the distribution that Lorenz dominates the other, implies a higher social welfare; if $F(x)$ y $G(x)$ are two income distributions of equal measurement, $\mu_{F}=\mu_{G}$ then:

$$
L_{F}(p) \geq L_{G}(p) \leftrightarrow \int U(x) f(x) d x \geq \int U(x) g(x) d x \quad \forall U(x)
$$

Such that $U^{\prime}(x)>0$ and $U^{\prime \prime}(x)<0(U(\bullet)$ is an strictly increasing and concave function)

b) Corollary Atkinson's Theorem: Atkinson's Theorem can still be fulfilled if the distribution dominated by Lorenz also has high income average. Considering the same assumption described in the theorem but with $\mu_{F}>\mu_{G}$ then:

$$
L_{F}(p) \geq L_{G}(p) \rightarrow \int U(x) f(x) d x \geq \int U(x) g(x) d x \quad \forall \quad U(x)
$$

c) Shorrocks Theorem: The Shorrocks theorem (1983), states that in the case that $\mu_{F}<$ $\mu_{G}$ it's possible to apply a generalized Lorenz curve. Given that $p=F(y)$, the generalized Lorenz curve $G L(p)$ for a distribution $F(x)$ could be defined:

$$
G L_{F}(p)=\int_{0}^{y} x f(x) d x=\mu_{F} L_{F}(p) y
$$

This allows reformulating the Atkinson theorem using Shorrocks Theorem (2003): Given $F(x)$ and $G(x)$ two income distributions, then:

$$
\int U(x) f(x) d x \geq \int U(x) g(x) d x \leftrightarrow G L_{F}(p) \geq G L_{G}(p) \quad \forall \quad p \in[0,1]
$$

In this way, its possible to apply the stochastic dominance concepts to unemployment duration, to this aim we first compare all the possible pair combinations of unemployment duration averages. These are presented in Table 4.

To analyze unemployment duration we exclude the cases that are considered outliers. The criteria to define the cut point in the distribution of employment duration was to eliminate all the cases in which unemployed individuals reported they had been looking for a job for over 48 months. The selection of this value was based on the frequencies of the analyzed variable for each year. We found that in all of them, more than $97 \%$ of the individuals were unemployed for less than 48 months.

As we have seen in the table above, from 1999 to 2003, the mean of unemployment duration is always less in the initial year than in the last, therefore corollary of Atkinson applies. However, by 2002-2003, 2003-2004 and 2003-2005 the mean of unemployment decreases according to Shorrocks' Theorem. The cases where none of the theorems were used are 2000-1999, 2001-1999 and 2005-2004.

In this case, when income is used as a variable of welfare, the interpretation given is different from the traditional one:

a) In all years, except in 2002-2003 and 2003-2004, the function of the last year is higher than the initial function, showing higher levels of unemployment duration.

b) In 2002-2003, 2003-2004 y 2003-2005, the initial year is higher than the last year, indicating less unemployment duration levels.

10 In the original article the variable used to measure well-being was income. In this case we will use unemployment duration as the variable. 
Given that in 1999-2000, 1999-2001 and 2004-2005 the graphics show intersections between the curves, it is impossible to carry out any comparison of welfare. For a graphical explanation we next present the Lorenz curves to illustrate.

Figure 2

\section{Generalized Lorenz curves 1998 to $2005^{11}$}
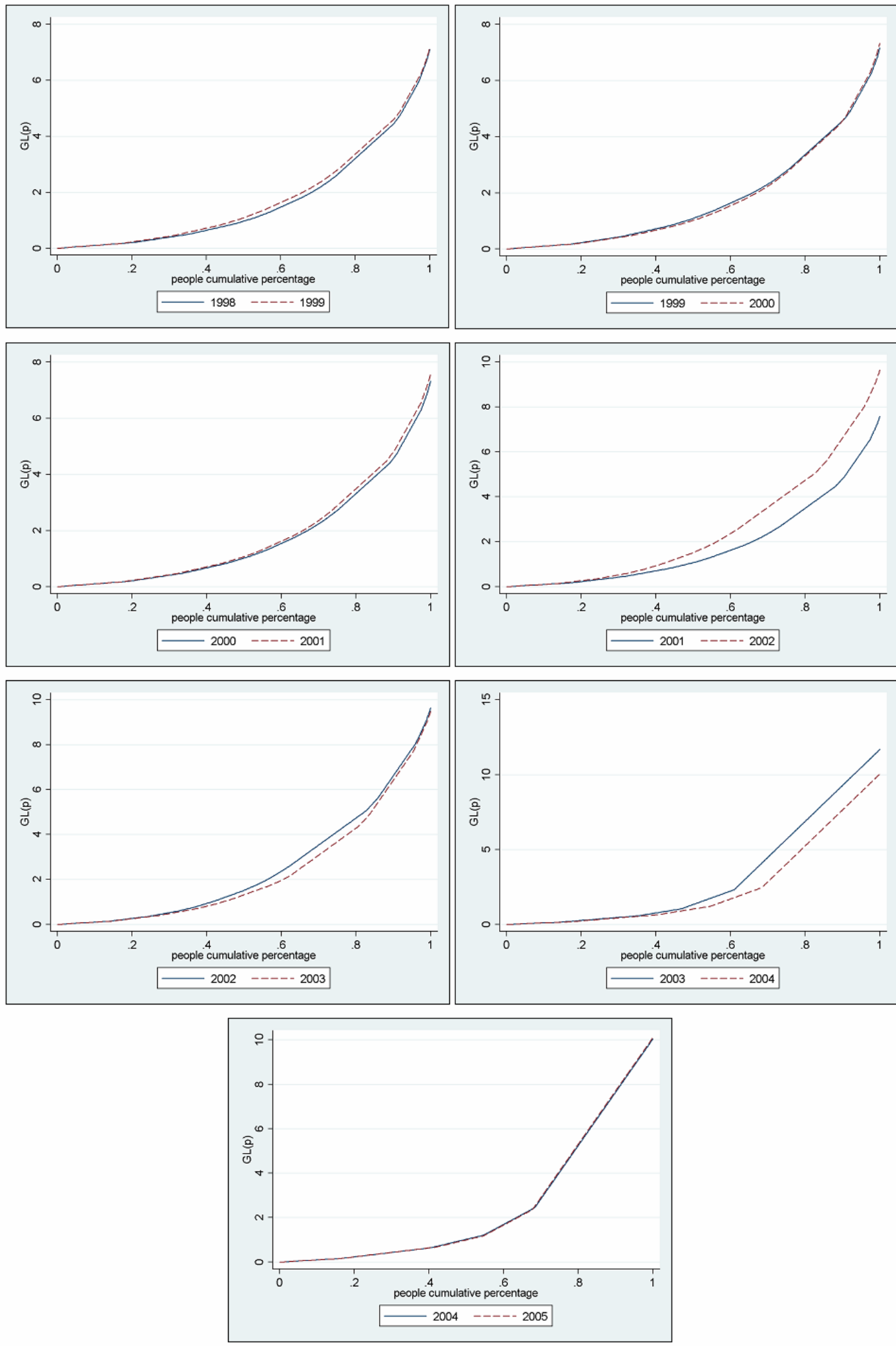

11 The remaining graphs can be found in the appendix. 


\section{a. Count Models and Unemployment Duration}

Count models are an alternative to analyze the determinants of unemployment duration. These determinants have as their dependent variable the discrete calculation of events (months of employment); additionally, it is necessary that the dependant variable is integer and its extension limited by zero ${ }^{12}$. The most used count models are the Poisson regression model and the negative binomial regression model.

Poisson regression models present one main problem - the over-dispersion of residuals, that is, the model underestimates the dispersion level of the result because its distribution assumes count variability within a group of covariants is equal to the mean. Also, standard errors of the Poisson regression would be skewed downwards.

In case this relation is not fulfilled, the estimated coefficients may be skewed, for this reason it is useful to compare it with the negative binomial regression model. This model takes into account this characteristic adding a parameter which reflects the heterogeneity not seen in the observations:

then:

$$
\ln \lambda_{i}=X_{i}{ }^{\prime} \beta+\varepsilon_{i}
$$

$$
\begin{gathered}
E\left(y_{i} / x_{i}, \varepsilon_{i}\right)=\hat{\lambda}_{i}=\exp \left(X_{i}{ }^{\prime} \beta+\varepsilon_{i}\right) \\
\hat{\lambda}_{i}=\exp \left(X_{i}{ }^{\prime} \beta\right) \exp \left(\varepsilon_{i}\right) \\
\hat{\lambda}_{i}=\exp \left(X_{i}{ }^{\prime} \beta\right) \delta_{i}
\end{gathered}
$$

Where $\delta_{i}=\exp \left(\varepsilon_{i}\right)$, to identify the model we assume that $E(\delta)=1$ which is equivalent to $E(\varepsilon)=0$. In this sense, Poisson and negative binomial distributions have the same mean structure.

Then the observations will follow a negative binomial distribution negative given by:

$$
P(y / x)=\frac{\Gamma\left(y+\alpha^{-1}\right)}{y ! \Gamma\left(\alpha^{-1}\right)}\left(\frac{\alpha^{-1}}{\alpha^{-1}+\lambda}\right)^{-1}\left(\frac{\lambda}{\alpha^{-1}+\lambda}\right)^{y}
$$

Where $\Gamma$ is the gamma function, one must take into account that the mean in this distribution (like in Poisson's) is $\lambda$, However, the variance is given by: $y+\frac{\lambda^{2}}{\alpha}$, where $\alpha$ is the dispersion parameter, when $a$ is high the negative binomial distribution converges to Poisson.

\section{i. Empirical strategy and results}

Taking advantage of the characteristics of the information from Argentinean household surveys, the negative binomial model was applied since we found over-dispersion of the residuals in Poisson model. Based on the theoretical definition, the following log-linear equation is estimated as:

12 Applying OLS models to this kind of data is inappropriate because it produces skewed and inefficient estimates. 


$$
\begin{aligned}
& \ln \left(\text { dur }_{i}\right)=\beta_{0}+\beta_{1} \text { pric }+\beta_{2} \sec i+\beta_{3} \sec c+\beta_{4} \sup i+\beta_{5} \operatorname{supc}+ \\
& \beta_{6} \text { jefe }+\beta_{7} \operatorname{sexo}+\beta_{8} \text { gedad } 1+\beta_{9} \operatorname{gedad} 2+\beta_{10} \text { bijos }+\beta_{11} g b a+\beta_{12} p o b+\varepsilon_{i}
\end{aligned}
$$

Where pric represents complete primary education, seci is incomplete secondary education, secc is complete secondary education, supi is incomplete superior education, supc is complete superior education, jefe is a dummy for the household head, sex is a dummy that takes one if the individual is female, gedad1 is a dummy for individuals between 15 to 29 years, gedad2 is a dummy for individuals between 30 to 50 years, hijos is the number of children in the household, gba is a dummy that takes the value of 1 if the individual lives in Great Buenos Aires ${ }^{13}$, pob is a dummy for poverty considering the poverty line index.

The variables used to estimate unemployment duration determinants are sociodemographic that can be found in the PHS. Since we are dealing with log-linear regressions, incidence ratios must be calculated. These ratios are basically antilogarithms of the coefficients ${ }^{14}$. The determinants of the unemployment duration proposed for analysis are discussed below.

To evaluate the effects of education on unemployment duration, dummy variables according to an educational level (completed primary school; completed and uncompleted secondary school, and completed and uncompleted higher education) were included. The expected coefficient in these variables is ambiguous, since there are studies, such as those by Rõõm (2002) and Steiger et. al.(2001) which show that higher levels of education would allow faster entry to employment, while other authors such as Kupets (2005), Pertiraca (2005) and Canavire and Landa (2006) argue that unemployment duration, in the case of people with low levels of education, is lower given the kind of employment they look for. ${ }^{15}$

If the individual is a household head, a dummy variable is included this is used to identify the predisposition to work due to the obligation with the family, therefore a decreasing relation (less than 1) on unemployment duration is expected. According to the previous empirical literature we would expect that the coefficient of gender for the dichotomic variable ( 0 for women and 1 for men) is decreasing (less than 1 ) since reservation wages are lower for men than for women.

Regarding age we would expect a positive coefficient for the older group and a negative coefficient in the younger group. The number of children in a household is included to capture the needs that a household member or spouse would have at the time of searching for a job, therefore we expect that the higher the number of children the lower the unemployment duration, which means a decreasing relation (less than 1).

A regional variable is included to analyze the effect of belonging to a particular region, more specifically a dummy for Great Buenos Aires ( 1 if the person lives in the area and 0 if lives elsewhere) was included. We choose this since this is region where most of the urban people live. Finally, we include a variable to capture the socioeconomic status, as a proxy we use the moderate poverty. We expect this variable to be negatively correlated with unemployment duration since poor people would need to find a job quicker.

\footnotetext{
${ }^{13}$ Great Buenos Aires is the main urban region in Argentina

14 Incidence ratios refer to the transformation of coefficients through $\mathrm{e}(\beta)$ since the estimates come from a log-linear model. Using this transformation we can estimate the real value of the coefficients.

15 The reservation wages for people with low education levels would be less, which would make their hiring easier.
} 
The estimation is carried out on individuals between 15 to 64, who were looking for employment between 1998 and 2005. The results are presented in Table 5. We found that there is a different effect between educational levels: lower educational levels have lower unemployment duration which supports part of the empirical evidence presented before, we also observe that the crisis period had harmful effect specially on the higher educational level groups, the incidence over unemployment duration decreased more in this group than in the lower educational levels group.

We found that the crisis had an initial shock in 2000 which caused a reduction of the effect of all educational levels; this implies that at the beginning of the period the effect over unemployment is reduced even if the unemployment rate increases which is due the fact that labour market absorbs faster the new unemployed but the persistence of this initial effect reduces over the years.

The dummy for household head has a decreasing effect over unemployment duration, before the crisis on average the condition of household decreases the unemployment duration in $17 \%$ while during the crisis period this percentage increases to $25 \%$ which implies that during this period the household head are more willing to accept any kind of job, presuming due to the responsibility that they might have.

The dummy for sex, implies that the condition of male decreases the unemployment time, somewhat surprising this effect reduces during the crisis period and start to decrease slowly after the crisis this shows that reservation wages of males are lower than for females which causes the males to go into the labour market, but it also shows that during crisis female tend to reduce their unemployment time. Looking at the age cohorts we found that the higher the age of the individuals the lower the reduction of unemployment, we don't find significant differences when we look at the crisis period. The job searching time decreases slightly with the number of children intuitively we could assume that the economic charge of a person increases when he has more dependants therefore accepting different kind of jobs.

The regional effect set by the Great Buenos Aires dummy does not have a significant effect either. A slightly higher effect is the one that the poverty variable present, especially during the crisis period. During this period the unemployment duration increases slightly compared to the periods without crisis. Finally, the constant term has a decreasing effect over the time, especially between 2003 to 2005 which is a sign of increasing in welfare of the society ${ }^{16}$ (see Table 5).

We should take into account that this analysis does not consider the kind of work that the individual can find which means that most of the possible jobs could be without social benefits. Next we present a short analysis to verify if the type of employment obtained influences the search time.

\section{b. Hazard Models and Unemployment Duration}

In this kind of models the endogenous variable we are interested in is the spell length $T$ in this case unemployment measured in months, which elapses from the beginning of some event until its end or until the measurement is taken, which may precede termination. Thus,

16 It should be noted that the year 2003 a change in the data collection - a transition from punctual to continuous survey - happened. 
in the duration analysis, censored spells can be taken into account. Suppose that the random variable $T$ has a continuous probability distribution $f(t)$ :

$$
F(t)-P(T \leq t)=\int_{0}^{t} f(u) d u
$$

The cumulative distribution $F(t)$ is the probability that the job searching do not reach $T$ while the density function correspond to the conditional probability that it is in fact $T$. To analyze unemployment duration its necessary to create a survival function $S(t)$ given by:

$$
S(t)=1-F(t)=P(T \geq t)=1-\int_{o}^{t} f(u) d u=\exp \left(-\int_{0}^{t} \lambda(u) d u\right.
$$

The hazard rate $\lambda$ is the rate at which spells are completed at time $t$, given that they have lasted until $t$.

$$
\lambda(t)=\lim _{\Delta t \rightarrow 0} \frac{\mathrm{P}(\mathrm{t} \leq \mathrm{T}<\mathrm{t}+\Delta \mathrm{t} \mid \mathrm{T} \geq \mathrm{t})}{\Delta \mathrm{t}}=\frac{f(t)}{S(t)}=\frac{f(t)}{1-F(t)}
$$

The hazard rate can be interpreted as the expected number of events in a one-unit time interval. The estimation procedure in this case is maximum likelihood based on the selected distribution function. In this paper we use the Weibull distribution function.

\section{i. Empirical strategy and results}

For this section we use a pooled survey for each consecutive couple of years. We separate individuals in three groups the first are the unemployed that remain unemployed, the second the ones that were unemployed during the initial spell but then found a job on informal sector, and finally the ones that were unemployed but found a job in a formal sector $^{17}$. To evaluate unemployment duration through hazard models the following specification is used:

$$
\begin{aligned}
& \ln \left(\text { dur }_{i t}\right)=\beta_{0}+\beta_{1} \text { pric }_{t-1}+\beta_{2} \sec _{t-1}+\beta_{3} \sec c_{t-1}+\beta_{4} \operatorname{supi}_{t-1}+\beta_{5} \sup c_{t-1}+\beta_{6} j e f e_{t-1} \\
& +\beta_{7} \text { sexo }_{t-1}+\beta_{8}{\text { gedad } 1_{t-1}+\beta_{9} \text { gedad }_{t-1}+\beta_{10} \text { bijos }_{t-1}+\beta_{11} \text { gba }}_{t-1}+\beta_{12} \text { pob }{ }_{t-1}+\beta_{13} p j h_{t-1}+\varepsilon_{i}
\end{aligned}
$$

The variables used here are the same as in the previous model, since one of the objectives of this section is to compare both models. However, we include the variable pjh which is a dummy for the people that participated in the "Plan Jefes o Jefas de Hogar", and it is used to evaluate the impact of this plan on the time of unemployment duration. The age cohort is the same as before (15 to 64). These two models include people who look for employment and find one after a certain time are, therefore it is possible to analyze if there are any differences between formal and informal employment ${ }^{18}$. The results are presented in Tables 6 and 7.

\footnotetext{
${ }^{17}$ An individual is classified as unemployed if he is looking for employment. Informal employment is defined the one where are individuals who are self-employed or work in a company with 1 to 5 employees or are unsalaried workers. Formal employment when an individual works, but it is not included in informal unemployment.

18 The sample used in this section is a smaller than in count models due to the characteristics of Argentinean household surveys.
} 
We could observe that between 2001 and 2002 the effect of crisis is present, specially over some variable like sex, old age and moderate poverty confirming the previous findings based on count models, even if the initial effect found on the binomial model is not so clear with this models we still observe a initial decrease on the effect of the main variables over unemployment duration to recover its effect after the crisis period. Educational levels show that between 1999-2000 the searching time for individuals moving towards informal sector is decreasing disregarding an educational level.

The dummy for household head shows an increasing trend on the transition in both sectors (informal and formal). Comparing the coefficients between 2000-2001 and 20032004 the effect is higher in the informal sector than in the formal sector, this could be due the effect of the crisis.

The dummy for males shows an increasing effect on unemployment duration towards formal and informal employment, therefore it can be concluded that men tend to spend more time looking for and finding a job than women. People aged 15 to 29 take more time finding informal than formal employment; at the same time people aged 30 to 50 take less time finding formal than informal employment.

The number of children generates an increasing effect in the time of search, although this time is much shorter in the case of informal employment. For people living in Greater Buenos Aires, despite the increasing tendency, it takes less time to find informal than formal employment, particularly during 2000-2001, 2002-2003 y 2003-2004.

Regarding moderate poverty, it is possible to see that before 2000-2001 the time to find informal employment was much longer. However, from 2001-2002 to 2004-2005 the search time had a decreasing tendency, just like formal employment. In the case of the "Plan Jefes o Jefas de Hogar", the time taken to find employment increases for those who find an informal job, which shows that it is more feasible to enter the plan in less time if one obtains a formal job.

Finally, the slopes, despite generally being increasing coefficients, show that the time of search is shorter for informal jobs than it is for formal ones, except during 2000-2001 and 2001-2002, perhaps due to the effects of the economic crisis in Argentina.

Since it has been proved that there are variables that affect the time of search for employment, below we analyze whether these variables affect the access and the possibility to find formal or informal employment, which means moving from unemployment to employment. For this purpose, we analyze the exit and predisposition to leave unemployment for any type of job, and if there are variations through 1998 to 2005.

\section{LABOUR MOBILITY AND ITS DETERMINANTS ${ }^{19}$}

Labour market dynamics are closely related to the evolution of the economy and welfare of the society, increases in product are related to increase in productivity in the labour markets, and recessions on the other hand are characterized by a deterioration of the labour markets switching employees towards less productive sectors. For this reason, and many others it is important to understand the labour mobility and its determinants especially during crisis periods. Labour mobility can be examined in two different ways; the

\footnotetext{
19 This section is based on the work developed by Jiménez y Jiménez (2003): "Occupational mobility and unemployment in the urban areas of Bolivia"
} 
first identifies occupational sectors based on labor market structure (for example, distinguishing between wage-earning workers, self-employed and employers) and then evaluating the existent degree of mobility of the variables determining inclusion to each category.

The second alternative is to identify segments depending on "entry", "allowance" and "mobility" which reflect different mechanisms of organization in the labor market ${ }^{20}$. This document uses the first form, dividing the labor market in unemployment, formal employment and informal employment.

\section{a. A brief methodological explanation}

To analyze the degree of labour mobility we apply the methodology adopted by Maloney (1999) in his study on labour mobility in Mexico, and later by Jimenez and Jimenez (2003) in Bolivia. To reach this aim we estimate the conditional probabilities Pij which reflect the probability to find a worker in sector $j$ at the end of a period, when the same worker began working in sector $i$ in the initial period. These probabilities can be standardized according to the size of the sector P.j, obtaining this way the relative probabilities Pij/P.j. A high coefficient of relative probability means a high probability of transition between sectors $i$ and $j$ and viceversa.

It should be noted that the relative probability (Pij/P.j) measures the degree of transition between two sectors, but the result is inaccurate since it does not take into account the ease of moving into the final sector. To overcome this problem we can calculate $V i j$ which includes the direction and degree of the occupational transition between occupational sectors and express the economic or institutional laws that force workers to leave the initial sector and take employment in the final sector (assuming that this latter exists).

Under this assumptions we can express the relation $P i j / P . j$ as follows:

$$
\frac{P_{i j}}{P_{. j}}=V_{i j}\left[\left(1-P_{i j}\right)\left(1-P_{i i}\right)\right]
$$

where we could estimate $V i j$ using:

$$
V_{i j}=\frac{\left(P_{i j} / P_{i j}\right)}{\left[\left(1-P_{i j}\right)\left(1-P_{i i}\right)\right]}
$$

It is important to notice that a high relative value of $V i j$ reflects a high predisposition of the workers to achieve this transition which means to switch from one state to the other, in all occupational sectors. It is expected, therefore, that high values of $V i j$ are associated with high predisposition to attain this transition while low values express a low tendency.

Given the intersectoral mobility, two forms of labour mobility can be identified: a) Occupational "shifts" that reflect the movements over the occupational structure; and b) employment and employers "rotation" within more or less similar occupations and where labour mobility is not associated to an occupational scale and therefore, do not show substantial changes in the income and social status of a worker. Both forms of mobility have substantially different consequences.

\footnotetext{
${ }^{20}$ For more details on this topic we suggest to see Doerengier y Piore (1973).
} 
In the first case, labour mobility is associated to changes in the labor market structure. If these changes respond to the needs of the demand and are associated to the characteristics of the supply, one then assumes that the labor market is flexible. The opposite happens if there is low intersectoral mobility, and especially if that mobility is not explained by the movements of the demand or by the productive characteristics of the supply.

Usually, occupational rotation is not related to substantial changes in the occupational structure. Constant change of employers or employment is generally a characteristic of unstable or precarious occupations, where high levels of mobility are not associated with significant changes in salaries, working stability or employment status.

To analyze employment mobility in Argentina, household surveys were used in individuals ages 15 to 64 from 1998 to 2005, estimating the conditional probabilities Pij to find a worker who started in sector $i$ in the initial spell $(i=j)^{21}$ but moved to sector $j$ at the end of the spell.

Figure 3

\section{Probability of moving from a labor market sector to other in each period}

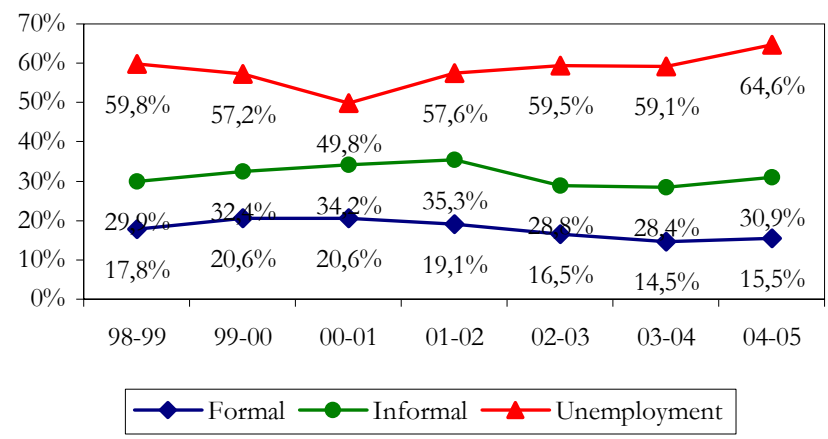

The evolution of the probability of moving out of each segment clearly shows the effect of the crisis, the probability of moving from unemployment into the formal or informal sector is reduced particularly during the crisis, reaching $49.8 \%$ in $2000-2001$, which differs from the previous period 1998-1999 in which the probability exit unemployment was $59.8 \%$. A sustained increment in the probability to exit unemployment was seen from 2001-2002. This result shows the little absorption of employment of the economy during crisis; this absorption reduces considerably in 2004-2005, giving a clear sing of improvement in the economy. It is important to note that these results are congruent with the evolution of the open unemployment rate presented before.

In relation to the informal sector, it is observed that the probability of exit increases notoriously between 1998 and 2002, and this is directly correlated to unemployment behavior. Subsequently, there is a sustained reduction in the probability of leaving the informal sector. A similar behaviour is seen in the formal sector, though the effect of the crisis is not as strong in this sector as it is in the informal sector and for the unemployed.

The transition matrices (Appendix) show high mobility amongst formal workers towards unemployment, particularly during the crisis; this shows how weak the informal sector of

\footnotetext{
${ }^{21}$ The graphs presented in all this section are the result of the tables obtained for this section; such tables are shown in the appendix.
} 
the economy is when there are shocks. This result is similar to the one found in the formal sector, but not as clear as before.

Over the economic expansion high levels of inactivity of the potential labor force have been faced, mostly attributable to increase on household incomes.

Figure 4

Predisposition to leave initial sector and reach final sector (Vij)
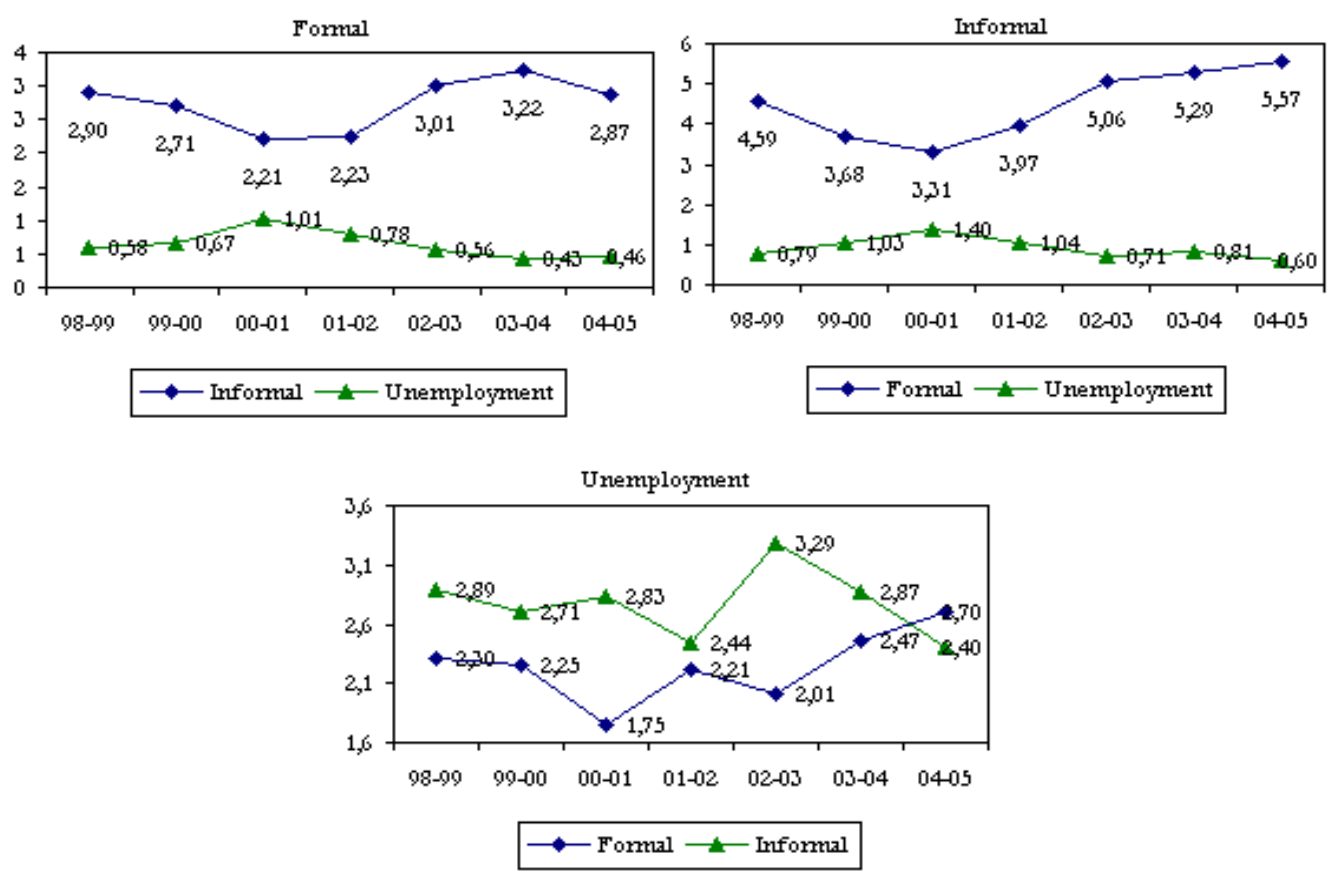

People showed lower predisposition to move from the formal to the informal sector from 1998-1999, where it reached 2.90, until 2001-2002 where it reached 2.23; from that year until 2003-2004 predisposition increases up to 3.22. The opposite happens when moving from formal employment to unemployment. From 1998-1999 to 2000-2001 increases from 0.058 to 1.01 and in 2004-2005 decreases down to 0.46.

Predisposition to move from the informal to formal sector is lower from 1998-1999 to 2000-2001, decreasing from 4.59 to 3.31 and increasing up to 5.57 in 2004-2005. The opposite occurs with the informal sector and unemployment, because from 1998-1999 to 2000-2001 there is an increase from 0.79 to 1.40 and then slowly decreases in 2004-2005 down to 0.60 .

Finally, the relation between unemployment and the formal sector tend to have lower predisposition from 1998-1999 to 2000-2001 decreasing from 3.30 to 1.75, and then gradually increasing until 2004-2005 up to 2.70. While unemployment tendency in the informal sector from 1998-1999 to 2001-2002 decreases from 2.89 to 2.44, then increases in 2003-2003 to 3.29 and finally it decreases again to 2.40 in 2004-2005. The graphs clearly show the effect of the economic situation in Argentina from 2000-2001 to 2002-2003.

When analyzing unemployment proportion in the formal and informal sectors, an inverse relation between the two "labor areas" is found, which means that there are effects on the type of employment obtained. 
Given that this study talks about unemployment and the analysis of the factors that influence the possible desertion of formal or informal employment, below there is an analysis to see if these factors are the same as those present in unemployment duration.5.2

\section{b. Probability work in determined sector}

To characterize mobility patterns in more detail, we use multinomial conditional logit models to choose the arrival sector, using determinants such as education (number of years), work experience, gender condition, place of residence, immigration or household responsibility. The estimated function corresponds to the following general form:

$$
\frac{P i j}{P i i}=e^{X \beta_{j}}
$$

Where $P_{i j} / P_{i i}$ represents the probability to move between sectors $i$ and $j$ with relation to the probability of staying in the initial sector. The vector of the estimated coefficients $\beta$ measures the degree in which individual characteristics of each worker $X$ change the probability for a worker to move to an occupation in sector $j$ relative to the probability to be in sector $i$.

The positive sign of the coefficients indicates that the characteristic associated to such estimator increases the possibility of change. On the other hand, a negative sign indicates that such characteristic reduces the above possibility. The estimates of the parameters in multinomial functions do not directly represent the slope as it is interpreted in a linear model $^{22}$. Therefore, it is necessary to calculate the marginal effects of the characteristics over the evaluated probabilities in the average of the observed characteristics. Therefore the equation can be written as:

$$
\ln \left[\frac{P i j}{P i i}\right]=\beta_{j} X_{i}
$$

Differentiating $\delta_{j}$, we obtain:

$$
\delta_{j}=\frac{P i j}{P i i}=P\left[\beta_{j}-\sum P_{k} \beta_{k}\right]=P_{j}\left[\beta_{j}-\bar{\beta}\right]
$$

That represents the change of occupation. Where $\beta=$ the adjusted mean

When calculating probabilities of transition, only those between unemployment and formal and informal formal occupations were considered ${ }^{23}$. The analysis of the probabilities of transition and the mobility patterns seen thanks to the model, give the tendencies to identify the characteristics of labour mobility in this market.

\section{i. Empirical strategy and results}

In the case of multinomial estimates, the regression coefficients only give an idea of the degree of signification and the direction of the effect caused by the independent variables. The estimation of the slope in the function, in the averages of the independent variables, is

\footnotetext{
22 See Kmenta, (1998); Greene (1998).

23 The aim of this study is not the division of sectors in employers or employees and self employed. Inactive individuals were not considered in the study either.
} 
known as the estimates of the marginal effects, and these are the ones that really matter for the analysis. The results obtained from this estimate help to establish some general hypothesis around labour mobility already discussed in a previous section, and can be used to support the previous unemployment duration.

The empirical specification used is:

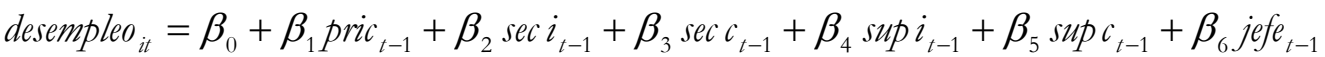

$$
\begin{aligned}
& +\beta_{7} \text { sexo }_{t-1}+\beta_{8}{\text { gedad } 1_{t-1}+\beta_{9} \text { gedad }_{t-1}+\beta_{10} \text { bijos }_{t-1}+\beta_{11} \text { gba }}_{t-1}+\beta_{12} \text { pob }{ }_{t-1}+\beta_{13} \text { pjh } \text { t }_{t-1}+\varepsilon_{i}
\end{aligned}
$$

Considering that all the surveys for each period are together, the variable unemployment, which takes a value of cero for individuals who are unemployed in the initial period and remain in that condition in the next period; and a value of one for those who move towards employment is used. To analyze those sectors which absorb labor force, a difference of the obtained occupation is made, between formal and informal. The results are presented in Tables 8 .

Based on the results from the multinomial logit estimates we observe that the more educated an individual is, the probability to get into a formal work is higher, on the other hand the probability to get a job in formal sectors of the economy is lower for those individuals that have lower educational levels, this trend remains over the period of analysis. On the other hand, the probability of entering into informal sector lower for the individuals with higher education; this result is quite intuitive as we would expect that, due to the characteristics of jobs in informal sectors: they require low educational training therefore it should be easier to enter this, moreover this sector has low wages which would repel high educated people from entering this sector.

During the crisis period the result shows that it became more difficult to enter informal markets for individuals with higher educational levels, but it also became easier for people with lower educational levels to enter the formal market; this shows the relative inflexibility of Argentinean labor market.

The dummy for a household head shows that the probability to find either formal or informal job is not stable over the period 1998-2005. However, if we observe between 2000 and 2001 finding informal employment was more likely than finding formal one, but then changing again in 2001-2001, perhaps due to the economic crisis, where it was unlikely to find any type of job.

The dummy for males initially shows more probability to find formal employment rather than informal, but between 2001-2002 and 2002-2003 there was an opposite effect; it was more likely to find employment in the informal sector than in the formal one. In the periods that followed, specifically between 2004 and 2005, these were positive but decreasing.

Age groups show that there was greater possibility to work in the formal sector than in the informal sector for younger people, this difference reduces during crisis period and show a bias towards informal markets. We can asses that crisis had the effect of reducing gaps, on probability, between older and younger people but at the same time had a harmful effect increasing the probability to enter to informal markets and reducing the probability of entering to formal markets. 
The number of children clearly shows the positive or negative effect on the possibility to enter formal or informal employment, yet we can see that the coefficients of the variable are opposite between each market; for example, 2003-2004 shows a positive coefficient for the informal sector and negative for the formal one.

Living in Great Buenos Aires, without taking into account the period 2001-2002, shows that there was more probability to work in the formal sector and less probability to move into the informal sector. The effects of the crisis are clearly seen from 2000-2001 to 20022003 years in which the coefficients are positive to obtain either formal or informal employment.

It was less likely for a person living in moderate poverty to work in the formal sector, for which reason one would believe that it is easier to enter the informal sector; and yet this affirmation can be seen only from 2002-2003 onwards. Moreover, it is possible that being part of the "Plan Jefes o Jefas de Hogar"" helped finding formal rather than informal employment, which would confirm the affirmation that such plan generates an employment policy towards formality.

To conclude, many of the variables suffered the effect of the economic conflict in Argentina, showing that even if coefficients were "stable", they underwent a change or a shock, which eventually returned to its original values.

\section{CONCLUSIONS}

This document analyzes the evolution and the determinants of unemployment duration and labour mobility in Argentina using household surveys carried out by INDEC from 1998 to 2005. During this period many changes have been going on in the labor markets. They affected unemployment duration and labour mobility mainly due to the effects caused by the crisis period, recession and recovery in Argentina. We observe an increase on unemployment rate during the crisis and later a slow decrease which shows the slow absorption that the economy has especially during crisis.

The results of the document show that there was deterioration in welfare terms on unemployment duration found using stochastic dominance curves this can be seen clearly during the crisis period. We found that individuals with high levels of education prefer to work in the formal sector but the time of search will be much longer and more difficult in a period of a crisis. Informal jobs have shorter periods of unemployment but they are characterized by low levels of education and can not face major changes caused by an economic crisis.

Therefore, the adjustment of wages is faster for less educated people. We also found an initial shock on unemployment duration which affected mainly the more educated people. The labour mobility results show that these groups in general enter easier formal labor markets which reduce the duration of the crisis. This, in its turn, would suggest that the more educated people tend to adjust their wages and push out of the market the less educated people. We could conclude that the human capital differences are crucial in the integration of workers and their ability to move between sectors, moreover this could have a close relation with the low social mobility in Argentina.

When an individual is a household head, even if unemployment duration decreased because of the obligation towards the family, the time of search for formal or informal employment increased. The possibility to work in the formal or informal sector does not 
show a clear stability to determine whether it affects entry to either labor sectors. The crisis reduces the time needed to find formal employment, perhaps because it offers certain working stability.

Males, despite decreasing the time of search to enter the labor market, experience an increasing effect on unemployment duration towards informal and informal employment. This result supports the evidence that the females have a higher reservation wages.

Age groups results show that there is a decreasing relation between age and unemployment duration. However, people aged 15 to 29 take longer to find informal employment than formal, while people aged 30 to 50 take less time to find formal employment than informal. In the analysis by age groups it is not possible to notice a difference in the possibility to work in the formal sector, even if it is more likely to work there than in the informal sector. Again, the effect of the crisis is seen in the age variable, especially in the calculated values.

The time of search for employment decreases according to the number of children an individual has. Living in Greater Buenos Aires presents an increasing tendency with less time of search towards informal employment, which is stronger during crisis; but because the place of residence of the individual is classed as urban, it is more probable to work in the formal sector and unlikely to move to the informal sector. The effects of the crisis can be clearly seen in this period since the coefficients are positive to get either formal or informal employment.

Moderate poverty shows that before the economic crisis the time needed to find informal employment was longer, but later the search period and formal employment have a decreasing tendency and it is less probable that an individual living in moderate poverty works in the formal sector, for which reason one may believe it is easier to enter the informal sector.

It is possible that the plan Jefes o Jefas de Hogar increases, for individuals, the time of search and the possibility to work in formal employment, therefore this plan generates an employment policy towards formality. Unemployment duration decreases with the years, especially from 2003 to 2005, which may indicate firstly that the time of search for employment is also decreasing; and secondly that unemployment duration towards informal employment is shorter than towards formal one, except between 2000-2001 and 2001-2002, perhaps due to the economic crisis in Argentina.

The labour mobility patterns do not reflect inflexibility in labour markets. To examine the barriers to mobility within groups it is necessary to examine the key role of inequalities on access to productive opportunities (education). Our results allow concluding that the apparent duality of the formal/informal in the Argentinean labour market, which seems to reflect differences in access to productive resources (human capital) outside the labor market, is the one that determine the integration into labour markets and later labour mobility of a big part of labour force. From this perspective policies directed to reduce the differences on distribution and access to productive resources (schools, universities) would lead to the situation when the integration is to be seen as mainly an individual preference decision, rather than a result of initial inequalities. 


\section{REFERENCES}

Atkinson, A.B. (1970). "On the measurement of Inequality", Journal of Economic Theory, 70, Vol. 2, No 3, September.

Beccaria, L. (1978). "Una contribución al estudio de la movilidad social en Argentina. Análisis de los resultados de una encuesta para el Gran Buenos Aires". Desarrollo Económico 17, págs. 593-618.

Beccaria L. y F. Goisman (2006). "Inestabilidad, movilidad y distribución del ingreso en Argentina”. Comisión Económica Para América Latina y El Caribe (CEPAL). Revista de la CEPAL $\mathrm{N}^{\circ} 89$ Santiago.

Beccaria L. y R. Maurizio (2003). "Movilidad ocupacional en Argentina". Asociación Argentina de Economía Política (AAEP). Documento de Trabajo Nro 1763.

Benoit L. y R. Giuliodori y J. Carballo y E. Peláez (2005). "Análisis de los factores de riesgo de desempleo en los asalariados urbanos. Gran Buenos Aires, Gran Córdoba, Gran Rosario. Periodo 1995-2003". Asociación Argentina de Economía Política (AAEP). Documento de Trabajo Nro 1921.

Canavire G. y F. Landa Casazola (2006). "Duración del desempleo en el área urbana de Bolivia: un análisis de los efectos de niveles de instrucción y características socioeconómicas". Unidad de Análisis de Politicas Sociales y Económicas (UDAPE). Revista de Análisis Económico No 21.

Castillo V. y M. Novick y S. Rojo y G. Yoguel (2006). "La movilidad laboral en Argentina desde mediados del decenio de 1990: El difícil camino de regreso al empleo formal". Comisión Económica Para América Latina y El Caribe (CEPAL). Revista de la CEPAL $\mathrm{N}^{\circ} 89$ Santiago.

Cerimedo, F. (2004). "Duración del Desempleo y Ciclo Económico en la Argentina". Centro de Estudios Distributivos, Laborales y Sociales (CEDLAS). Documento de Trabajo Nro. 8.

Cid J. C. y J. A. Paz (2001). "El tránsito por el desempleo en la Argentina. Determinantes y consecuencias sobre el empleo". Asociación Argentina de Economía Política (AAEP). Documento de Trabajo Nro 1568.

Cid J. C. y J. A. Paz (2002). "El desempleo y el empleo irregular como estigmas". Asociación Argentina de Economía Politica (AAEP). Documento de Trabajo Nro 1678.

Cortés R y F. Groisman (2004). "Migraciones, mercado de trabajo y pobreza en el Gran Buenos Aires". Comisión Económica Para América Latina y El Caribe (CEPAL). Revista de la CEPAL No 89 Santiago.

Doeringer P. B. y M. J. Piore. (1985). "Internal Labor Markets and Manpower Analysis". (2d.edition) London: M.E. Sharpe, Inc.

Galiani, S. y H. Hopenhayn (2001). "Duration and Risk of Unemployment in Argentina”. Universidad de San Andrés (UDESA). Working Paper Nro 40.

Gasparini, L. (2005). "Protección Social y Empleo en América Latina: Estudio sobre la Base de Encuestas de Hogares". Centro de Estudios Distributivos, Laborales y Sociales (CEDLAS). Documento de Trabajo Nro. 17.

Germani, G. (1963). "Movilidad social en Argentina", págs. 317-65 en Apéndice II agregado a la versión castellano de Lipset, S.M. y Bendix, R. Movilidad social en la sociedad industrial. Buenos Aires. Eudeba. 
Golbert, L. (2004). "Derecho a la inclusión o paz social? Plan Jefas y Jefes de Hogar Desocupados". Comisión Económica Para América Latina y El Caribe (CEPAL). Serie Políticas Sociales No 84 Santiago.

González, S. M. (2003). "Inserción laboral, desajuste educativo y trayectorias laborales de los titulados en formación profesional específica en la isla de gran canaria (1997-2000)". Universidad de Las Palmas de Gran Canaria. Departamento de Métodos Cuantitativos en Economía y Gestión. Tesis doctoral.

Greene, H. W. (1998). “Análisis Econométrico”, Prentice Hall: Tercera edición, Madrid.

Gutierrez, F. H. (2004). "Dinámica Salarial y Ocupacional: Análisis de Panel para Argentina 1998-2002". Centro de Estudios Distributivos, Laborales y Sociales (CEDLAS). Documento de Trabajo Nro. 11.

Heckman, J. y B. Singer (1984). "Econometric Duration Analysis" Journal of Economic Literature Vol 26.

Jiménez E. y W. Jiménez Pozo (2003). "Movilidad ocupacional y desempleo en el área urbana de Bolivia". Unidad de Análisis de Politicas Sociales y Económicas (UDAPE). Revista de Análisis Económico No 18.

Kessler G. y V. Espinoza (2003). "Movilidad social y trayectorias ocupacionales en Argentina: rupturas y algunas paradojas del caso de Buenos Aires". Comisión Económica Para América Latina y El Caribe (CEPAL). Serie Políticas Sociales No 66 Santiago.

Kmenta. (1995). "Elements of Econometrics".

Kupets, O. (2005). "Determinants of unemployment duration in Ukraine" Economics research Network Russia and CIS. No $05 / 01$.

Jorrat, J. R. (1997). "En las huellas de los padres: movilidad ocupacional en el Buenos Aires de 1980". Desarrollo Económico 37, págs. 91-116.

Jorrat, J. R. (2005). "Aspectos descriptivos de la movilidad intergeneracional de clase en Argentina: 2003-2004”. Laboratorio. Cambio Estructural y Desigualdad Social. Año 7 • Número $17 / 18 \cdot$ Invierno/Primavera.

Lamarche C. y A. Porto y W. Sosa Escudero (1998). "Aspectos regionales del desempleo en Argentina". Asociación Argentina de Economía Politica (AAEP). Documento de Trabajo Nro 1327.

Lancaster, T. (1990). "The econometric Analysis of transition data" Cambridge University Press, Economic Society Monographs. No 17.

Martin, J.L. (1995). "Paro y Búsqueda de4 Empleo. Una aproximación desde la teoría económica" Universidad de Sevilla, Secretariado de Publicaciones, Serie: Ciencias Económicas y Empresariales, $\mathrm{N}^{\mathrm{o}} 31$.

Maloney W.F. (1999). "Does Informality Imply Segmentation in Urban Labor Markets?, Evidence from Sectorial Transitions in Mexico". The World Bank Economic Review. Vol 13, Number 2.

Mitnik, O. A. (1999). "Notas docentes sobre Distribución del Ingreso y Pobreza". Programa de Postgrado en Economía. ILADES-Georgetown University.

Ministerio de Trabajo, Empleo y Seguridad Social (2005). "Trabajo, ocupación y empleo. Trayectorias, negociación colectiva e ingresos". Serie de Estudios de Trabajo, Ocupación y Empleo $\mathrm{N}^{\mathrm{o}}$ 2. Subsecretaría de Programación Técnica y Estudios Laborales, Buenos Aires. 
Rõõm, M. (2002). "Unemployment and labour mobility in Estonia: Analysis using duration models". Working Paper 1/ 2003N. Eesti Pank.

Ronconi, L. (2001). "Informalidad laboral e inspección del trabajo en argentina. un enfoque institucional". Centro de Estudios para el Desarrollo Institucional, Fundación Gobierno y Sociedad. Documento $\mathrm{N}^{\circ} 46$.

Shorrocks, A. (1983). "Ranking Income Distributions." Economica 50: 3-17.

Steiger, D., J. y J. Stock y M. Watson (1997). "The NAIRU, Unemployment and Monetary Policy" Journal of Economic Perspectives. Vol 11 N 1.

Van den Berg, G. J. (2001). "Duration Models: Specification, Identification and Multiple Durations" in J. Heckman and E. Leamer eds. Handbook of Econometrics Volume V.

Van Ours, J.C. y Van den Berg, G.J. (1996). "Unemployment dynamics and duration dependence", Journal of Labour Economics. 14 100-125.

Van den Berg, G. J. y J.C. Van Ours (1994). "Unemployment Dynamics and Duration Dependence in France, the Netherlands and the United Kingdom" Economic Journal, 104 432-443.

Van den Klaaw, Bas y Van den Berg, G. J. (2001) "Counselling and Monitoring of Unemployed Workers: Theory and Evidence from a Controlled Social Experiment" Centre for Economic and Policy Research. Discussion Paper N 2986

Vinocur P. y L. Halperin (2004). "Pobreza y políticas sociales en Argentina de los años noventa". Comisión Económica Para América Latina y El Caribe (CEPAL). Serie Políticas Sociales $\mathrm{N}^{\mathrm{o}} 85$ Santiago.

Yañez, A. (2004). "Algunas Consideraciones sobre la Medida del Desempleo y la Distribución de la Duración Del Paro". Universidad Autónoma de Barcelona, Depto. Economía Aplicada. Mimeo 


\section{$\underline{\text { APPENDIX }}$}

Table 1

Argentina: Labour market indicators, population older than 15 years, 1998-2005 (In percentage)

\begin{tabular}{|c|c|c|c|c|c|c|c|c|c|c|}
\hline & \multicolumn{6}{|c|}{ EPH } & \multicolumn{3}{|c|}{ EPH-C } & \\
\hline Years & 1998 & 1999 & 2000 & 2001 & 2002 & 2003 & $\begin{array}{c}\text { 2003- } \\
\text { II }\end{array}$ & $\begin{array}{c}\text { 2004- } \\
\text { II }\end{array}$ & $\begin{array}{c}\text { 2004- } \\
\text { II }\end{array}$ & Average \\
\hline Employment & 50 & 49.7 & 49.5 & 46.4 & 47.6 & 48.7 & 51.9 & 54 & 55.2 & 50.3 \\
\hline Informal Sector & 42.8 & 43.2 & 44.2 & 44.6 & 43 & 42.5 & 43.7 & 42.9 & 41.8 & 43.2 \\
\hline Unemployment rate & 12.5 & 13.9 & 14.8 & 18.4 & 17.9 & 15.7 & 15.4 & 12.6 & 10.6 & 14.6 \\
\hline
\end{tabular}

Table 2

Argentina: Unemployment duration characteristics, 1998-2005

(In Months)

\begin{tabular}{|c|c|c|c|c|c|c|c|c|c|c|c|}
\hline & \multirow[b]{3}{*}{ Total } & \multirow{2}{*}{\multicolumn{3}{|c|}{ Age }} & \multicolumn{5}{|c|}{ Adults (25-64) } & \multirow{2}{*}{\multicolumn{2}{|c|}{$\frac{\text { Young (15-24) }}{\text { Sex }}$}} \\
\hline & & & & & \multicolumn{2}{|c|}{ Sex } & \multicolumn{3}{|c|}{ Education } & & \\
\hline & & $(15-24)$ & $(25-64)$ & $(65+)$ & Female & Male & Low & Medium & High & Female & Male \\
\hline $\mathrm{EPH}$ & & & & & & & & & & & \\
\hline October 1998 & 6.1 & 5.5 & 6.5 & 4.7 & 8.7 & 4.7 & 5.8 & 6.6 & 8.4 & 6.1 & 5.1 \\
\hline October 1999 & 6.4 & 5.9 & 6.6 & 8.7 & 8.6 & 4.9 & 5.5 & 6.5 & 9.3 & 6.6 & 5.3 \\
\hline October 2000 & 6.6 & 6.3 & 6.8 & 6.0 & 8.9 & 5.1 & 6.1 & 7.1 & 8.5 & 7.2 & 5.5 \\
\hline October 2001 & 6.8 & 7.0 & 6.7 & 9.5 & 8.3 & 5.7 & 6.1 & 6.8 & 8.4 & 8.1 & 6.1 \\
\hline October 2002 & 8.9 & 8.7 & 8.8 & 18.4 & 11.1 & 7.1 & 7.2 & 9.4 & 11.1 & 9.3 & 8.2 \\
\hline May 2003 & 8.5 & 7.6 & 8.9 & 11.1 & 11.8 & 7.2 & 7.9 & 9.3 & 10.2 & 7.8 & 7.4 \\
\hline EPH-C & & & & & & & & & & & \\
\hline 2003-II & 11.7 & 10.6 & 12.4 & 13.0 & 13.8 & 11.0 & 12.4 & 11.8 & 13.5 & 11.2 & 10.1 \\
\hline 2004-I & 10.7 & 9.2 & 11.6 & 11.1 & 13.4 & 9.8 & 10.7 & 11.9 & 12.7 & 9.7 & 8.7 \\
\hline 2004-II & 10.0 & 9.2 & 10.6 & 9.8 & 12.0 & 9.2 & 9.6 & 11.2 & 11.7 & 10.2 & 8.3 \\
\hline 2005-I & 9.8 & 8.4 & 10.7 & 11.4 & 12.0 & 9.3 & 9.5 & 11.8 & 10.7 & 8.7 & 8.0 \\
\hline 2005-II & 10.2 & 8.8 & 11.0 & 13.7 & 12.6 & 9.1 & 10.6 & 10.9 & 12.2 & 8.9 & 8.8 \\
\hline
\end{tabular}


Table 3

Argentina: Employment structure by sector, 1998-2005

(In percentage)

\begin{tabular}{lccccccccccc} 
& \multicolumn{1}{c}{ EPH } & \multicolumn{1}{c}{ EPH-C } \\
\hline & Oct. & Oct. & Oct. & Oct. & Oct. & Mayo & $2003-$ & $2004-$ & $2004-$ & $2005-$ & $2005-$ \\
Item & 1998 & 1999 & 2000 & 2001 & 2002 & 2003 & II & I & II & I & II \\
\hline Primary sector & 1.0 & 1.0 & 0.8 & 1.1 & 1.4 & 1.4 & 1.7 & 1.7 & 1.5 & 1.4 & 1.4 \\
Textiles and food & 5.8 & 5.6 & 5.8 & 5.4 & 5.5 & 6.1 & 7.7 & 7.8 & 7.9 & 7.7 & 7.6 \\
Industry & 9.6 & 9.0 & 8.2 & 8.3 & 7.3 & 6.7 & 6.1 & 6.4 & 6.6 & 6.9 & 6.6 \\
Construction & 8.5 & 8.4 & 7.9 & 7.2 & 6.7 & 6.5 & 7.1 & 7.6 & 7.8 & 8.0 & 8.6 \\
Commerce & 23.3 & 22.8 & 24.0 & 24.0 & 21.8 & 22.0 & 23.3 & 23.7 & 24.2 & 23.1 & 23.6 \\
Transportation and & & & & & & & & & & & \\
services & 8.2 & 9.0 & 8.7 & 8.5 & 7.6 & 7.6 & 7.1 & 6.9 & 7.4 & 7.2 & 7.3 \\
Professional services & 9.5 & 9.7 & 9.6 & 9.0 & 9.1 & 9.4 & 9.0 & 9.1 & 8.7 & 9.9 & 9.4 \\
Public sector & 7.7 & 7.6 & 7.8 & 8.4 & 10.3 & 9.1 & 8.9 & 8.7 & 8.1 & 7.7 & 7.6 \\
Education and health & 18.9 & 19.1 & 19.3 & 20.2 & 23.3 & 24.1 & 21.3 & 20.5 & 20.2 & 20.4 & 20.3 \\
Domestic Service & 7.6 & 7.7 & 7.9 & 7.9 & 6.9 & 7.0 & 7.6 & 7.5 & 7.5 & 7.7 & 7.7 \\
\hline \multicolumn{1}{c}{ Source: CEDLAS } & & & & & & & & & & &
\end{tabular}

Table 4

Comparison of average unemployment duration ${ }^{24}$

\begin{tabular}{ccccc}
\hline Years & $\mu_{F}$ & & $\mu_{G}$ & item \\
\hline $1999-1998$ & 7.22 & $>$ & 7.04 & Atkinson Corollary \\
$2000-1998$ & 7.31 & $>$ & 7.04 & Atkinson Corollary \\
$2001-1998$ & 7.43 & $>7.04$ & Atkinson Corollary \\
$2002-1998$ & 9.52 & $>$ & 7.04 & Atkinson Corollary \\
$2003-1998$ & 9.26 & $>$ & 7.04 & Atkinson Corollary \\
$2002-1999$ & 9.52 & $>$ & 7.22 & Atkinson Corollary \\
$2003-1999$ & 9.26 & $>$ & 7.22 & Atkinson Corollary \\
$2001-2000$ & 7.43 & $>7.31$ & Atkinson Corollary \\
$2002-2000$ & 9.52 & $>7.31$ & Atkinson Corollary \\
$2003-2000$ & 9.26 & $>7.31$ & Atkinson Corollary \\
$2002-2001$ & 9.52 & $>7.43$ & Atkinson Corollary \\
$2003-2001$ & 9.26 & $>7.43$ & Atkinson Corollary \\
$2003-2002$ & 9.26 & $<$ & 9.52 & Shorrocks Theorem \\
$2004-2003$ & 9.82 & $<11.52$ & Shorrocks Theorem \\
$2005-2003$ & 10.00 & $<11.52$ & Shorrocks Theorem \\
\hline
\end{tabular}

${ }^{24}$ For the year 2003, the value changes from 9.26 to 11.56 due to the change of the collection of the data in two different ways the same year. 
Table 5

Argentina-Unemployment duration: Negative Binomial estimates

\begin{tabular}{|c|c|c|c|c|c|c|c|c|}
\hline Variables & 1998 & 1999 & 2000 & 2001 & 2002 & 2003 & 2004 & 2005 \\
\hline Observations & 3,142 & 3,257 & 3,558 & 4,281 & 3,904 & 4,182 & 3,768 & 3,191 \\
\hline Wald chi $^{2}$ & 57.21 & 94.96 & 64.35 & 89.66 & 59.00 & 67.41 & 101.13 & 84.36 \\
\hline Prob $>$ chi $^{2}$ & 0.0000 & 0.0000 & 0.0000 & 0.0000 & 0.0000 & 0.0000 & 0.0000 & 0.0000 \\
\hline \multirow[t]{2}{*}{ Complete primary } & 1.051 & 1.049 & 0.840 & 1.013 & 1.113 & 1.061 & 1.228 & 1.138 \\
\hline & $(0.123)$ & $(0.150)$ & $(0.108)$ & $(0.112)$ & $(0.144)$ & $(0.108)$ & $(0.151)$ & $(0.132)$ \\
\hline \multirow[t]{2}{*}{ Incomplete secondary } & 1.200 & 1.104 & 0.885 & 1.077 & 1.242 & 0.967 & 1.327 & 1.043 \\
\hline & $(0.142)$ & $(0.161)$ & $(0.116)$ & $(0.121)$ & $(0.158)$ & $(0.102)$ & $(0.163)$ & $(0.120)$ \\
\hline \multirow[t]{2}{*}{ Complete secondary } & 1.286 & 1.146 & 0.926 & 1.099 & 1.335 & 0.997 & 1.423 & 1.200 \\
\hline & $(0.165)$ & $(0.174)$ & $(0.121)$ & $(0.125)$ & $(0.173)$ & $(0.105)$ & $(0.176)^{* *}$ & $(0.141)$ \\
\hline \multirow[t]{2}{*}{ Incomplete Superior Ed. } & 1.279 & 1.165 & 0.926 & 1.226 & 1.422 & 1.018 & 1.487 & 1.226 \\
\hline & $(0.180)$ & $(0.179)$ & $(0.131)$ & $(0.153)$ & $(0.203)$ & $(0.113)$ & $(0.188)^{* *}$ & $(0.149)$ \\
\hline \multirow[t]{2}{*}{ Complete Superior Ed. } & 1.208 & 1.365 & 0.895 & 1.083 & 1.450 & 1.168 & 1.448 & 1.497 \\
\hline & $(0.198)$ & $(0.247)$ & $(0.158)$ & $(0.150)$ & $(0.239)$ & $(0.151)$ & $(0.194)^{*}$ & $(0.194)^{* *}$ \\
\hline \multirow[t]{2}{*}{ Household head } & 0.907 & 0.748 & 0.753 & 0.738 & 0.758 & 0.796 & 0.835 & 0.746 \\
\hline & $(0.077)$ & $(0.064)^{* *}$ & $(0.058)^{* * *}$ & $(0.052)^{* * *}$ & $(0.070)^{* *}$ & $(0.052)$ & $(0.057)^{*}$ & $(0.054)^{* * *}$ \\
\hline \multirow[t]{2}{*}{ Sex } & 0.758 & 0.762 & 0.757 & 0.812 & 0.824 & 0.839 & 0.753 & 0.801 \\
\hline & $(0.049)^{* * *}$ & $(0.048)^{* * *}$ & $(0.045)^{* * *}$ & $(0.045)^{* * *}$ & $(0.058)^{*}$ & $(0.038)$ & $(0.037)^{* * *}$ & $(0.040)^{* * *}$ \\
\hline \multirow[t]{2}{*}{ Age 15 to 29} & 0.660 & 0.711 & 0.629 & 0.666 & 0.715 & 0.724 & 0.609 & 0.618 \\
\hline & $(0.073)^{* * *}$ & $(0.081)^{* *}$ & $(0.068)^{* * *}$ & $(0.061)^{* * *}$ & $(0.080)^{* *}$ & $(0.054)$ & $(0.052)^{* * *}$ & $(0.052)^{* * *}$ \\
\hline \multirow[t]{2}{*}{ Age 30 to 50} & 0.780 & 0.939 & 0.776 & 0.838 & 0.846 & 0.913 & 0.727 & 0.716 \\
\hline & $(0.086)$ & $(0.106)$ & $(0.087)$ & $(0.080)$ & $(0.082)$ & $(0.06)$ & $(0.058)^{* * *}$ & $(0.060)^{* * *}$ \\
\hline \multirow[t]{2}{*}{ Children } & 0.962 & 0.904 & 0.955 & 0.959 & 0.973 & 0.977 & 0.999 & 1.026 \\
\hline & $(0.025)$ & $(0.021)^{* * *}$ & $(0.024)$ & $(0.021)$ & $(0.029)$ & $(0.023)$ & $(0.027)$ & $(0.025)$ \\
\hline \multirow[t]{2}{*}{ GBA } & 1.037 & 0.970 & 0.967 & 1.050 & 1.075 & 1.053 & 0.845 & 0.933 \\
\hline & $(0.057)$ & $(0.052)$ & $(0.051)$ & $(0.049)$ & $(0.059)$ & $(0.04)$ & $(0.037)^{* * *}$ & $(0.041)$ \\
\hline \multirow[t]{2}{*}{ Moderate poverty } & 0.911 & 1.008 & 1.035 & 0.971 & 1.117 & 0.980 & 0.927 & 1.051 \\
\hline & $(0.060)$ & $(0.063)$ & $(0.064)$ & $(0.054)$ & $(0.085)$ & $(0.047)$ & $(0.046)$ & $(0.054)$ \\
\hline \multirow[t]{2}{*}{$\operatorname{Ln}($ Alfa $)$} & -0.302 & -0.383 & -0.273 & -0.305 & -0.368 & -0.142 & -0.047 & -0.029 \\
\hline & $(0.037)$ & $(0.041)$ & $(0.033)$ & $(0.031)$ & $(0.042)$ & $(0.02)$ & $(0.017)$ & $(0.017)$ \\
\hline \multirow[t]{2}{*}{ Alfa } & 0.739 & 0.682 & 0.761 & 0.737 & 0.692 & 0.868 & 0.954 & 0.971 \\
\hline & $(0.027)$ & $(0.028)$ & $(0.025)$ & $(0.023)$ & $(0.029)$ & $(0.018)$ & $(0.016)$ & $(0.017)$ \\
\hline
\end{tabular}

Note: Standard errors in parenthesis 
Table 6

Argentina-Unemployment duration: Weibull estimates from Unemployment to Formal sector

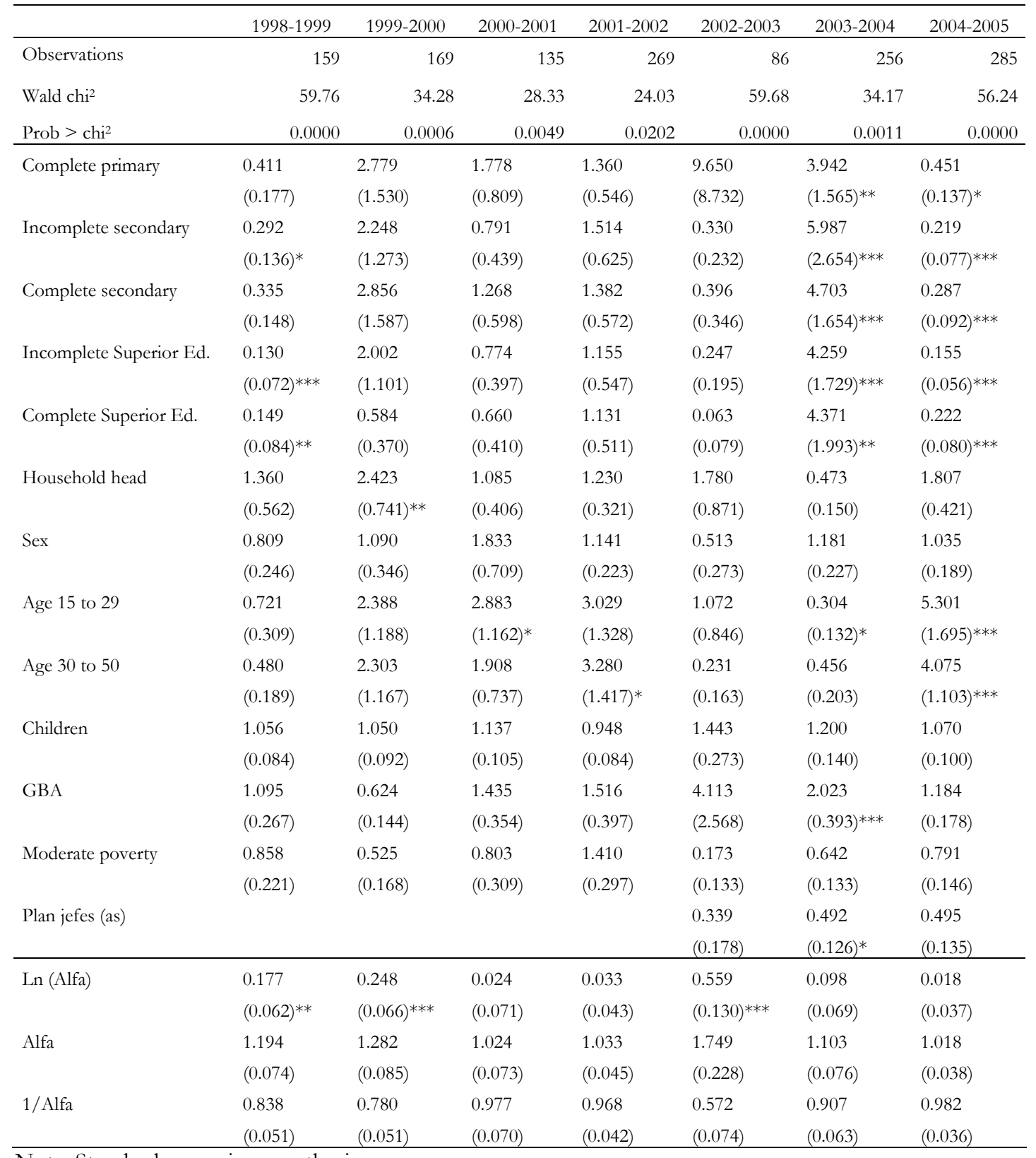

Note: Standard errors in parenthesis 
Table 7

Argentina-Unemployment duration: Weibull estimates from Unemployment to informal sector

\begin{tabular}{|c|c|c|c|c|c|c|c|}
\hline & 1998-1999 & $1999-2000$ & $2000-2001$ & 2001-2002 & 2002-2003 & 2003-2004 & 2004-2005 \\
\hline Observations & 266 & 275 & 248 & 303 & 152 & 356 & 344 \\
\hline Wald chi ${ }^{2}$ & 37.16 & 40.16 & 32.13 & 39.06 & 39.71 & 20.77 & 19.02 \\
\hline Prob $>$ chi $^{2}$ & 0.0002 & 0.0001 & 0.0013 & 0.0001 & 0.0002 & 0.0776 & 0.1224 \\
\hline \multirow[t]{2}{*}{ Complete primary } & 0.438 & 0.678 & 0.793 & 0.707 & 0.285 & 0.893 & 0.698 \\
\hline & $(0.136)^{*}$ & $(0.217)$ & $(0.237)$ & $(0.235)$ & $(0.173)$ & $(0.224)$ & $(0.248)$ \\
\hline \multirow[t]{2}{*}{ Incomplete secondary } & 0.523 & 0.534 & 0.686 & 0.770 & 0.084 & 0.835 & 0.661 \\
\hline & $(0.170)$ & $(0.160)$ & $(0.232)$ & $(0.244)$ & $(0.054)^{* * *}$ & $(0.238)$ & $(0.211)$ \\
\hline \multirow[t]{2}{*}{ Complete secondary } & 0.468 & 0.671 & 0.690 & 0.492 & 0.179 & 0.702 & 0.537 \\
\hline & $(0.182)$ & $(0.229)$ & $(0.291)$ & $(0.165)$ & $(0.108)^{* *}$ & $(0.184)$ & $(0.177)$ \\
\hline \multirow[t]{2}{*}{ Incomplete Superior Ed. } & 1.256 & 0.507 & 0.564 & 1.073 & 0.035 & 0.678 & 0.777 \\
\hline & $(0.461)$ & $(0.190)$ & $(0.272)$ & $(0.481)$ & $(0.030)^{* * *}$ & $(0.214)$ & $(0.260)$ \\
\hline \multirow[t]{2}{*}{ Complete Superior Ed. } & 2.243 & 0.992 & 0.411 & 0.605 & 0.128 & 0.637 & 0.726 \\
\hline & $(0.991)$ & $(0.323)$ & $(0.226)$ & $(0.306)$ & $(0.093)^{*}$ & $(0.207)$ & $(0.356)$ \\
\hline \multirow[t]{2}{*}{ Household head } & 0.963 & 1.161 & 2.064 & 1.799 & 2.104 & 1.154 & 1.033 \\
\hline & $(0.301)$ & $(0.336)$ & $(0.617)$ & $(0.470)$ & $(0.989)$ & $(0.241)$ & $(0.208)$ \\
\hline \multirow[t]{2}{*}{ Sex } & 0.950 & 2.072 & 1.552 & 1.424 & 1.236 & 1.366 & 1.078 \\
\hline & $(0.221)$ & $(0.453)^{* *}$ & $(0.318)$ & $(0.286)$ & $(0.537)$ & $(0.203)$ & $(0.178)$ \\
\hline \multirow[t]{2}{*}{ Age 15 to 29} & 0.988 & 1.148 & 3.821 & 1.004 & 2.570 & 1.164 & 1.312 \\
\hline & $(0.353)$ & $(0.460)$ & $(1.324)^{* * *}$ & $(0.294)$ & $(1.346)$ & $(0.303)$ & $(0.357)$ \\
\hline \multirow[t]{2}{*}{ Age 30 to 50} & 0.755 & 1.418 & 1.425 & 0.838 & 1.326 & 0.995 & 1.285 \\
\hline & $(0.240)$ & $(0.514)$ & $(0.424)$ & $(0.229)$ & $(0.563)$ & $(0.254)$ & $(0.363)$ \\
\hline \multirow[t]{2}{*}{ Children } & 1.048 & 1.018 & 1.066 & 0.923 & 1.016 & 1.105 & 1.052 \\
\hline & $(0.095)$ & $(0.068)$ & $(0.088)$ & $(0.071)$ & $(0.182)$ & $(0.084)$ & $(0.075)$ \\
\hline \multirow[t]{2}{*}{ GBA } & 1.143 & 1.066 & 1.147 & 1.676 & 1.385 & 1.118 & 1.401 \\
\hline & $(0.206)$ & $(0.186)$ & $(0.211)$ & $(0.291)^{* *}$ & $(0.491)$ & $(0.178)$ & $(0.213)$ \\
\hline \multirow[t]{2}{*}{ Moderate poverty } & 1.792 & 1.150 & 1.057 & 0.795 & 0.424 & 0.989 & 0.979 \\
\hline & $(0.455)$ & $(0.219)$ & $(0.235)$ & $(0.128)$ & $(0.187)$ & $(0.176)$ & $(0.174)$ \\
\hline \multirow[t]{2}{*}{ Plan jefes(as) } & & & & & 0.317 & 1.399 & 1.571 \\
\hline & & & & & $(0.257)$ & $(0.997)$ & $(0.429)$ \\
\hline \multirow[t]{2}{*}{ Ln (Alfa) } & 0.020 & 0.093 & 0.109 & 0.168 & 0.166 & -0.079 & -0.133 \\
\hline & $(0.047)$ & $(0.049)$ & $(0.058)$ & $(0.044)^{* * *}$ & $(0.088)$ & $(0.039)$ & $(0.027)^{* * *}$ \\
\hline \multirow[t]{2}{*}{ Alfa } & 1.021 & 1.098 & 1.115 & 1.182 & 1.180 & 0.924 & 0.875 \\
\hline & $(0.048)$ & $(0.053)$ & $(0.065)$ & $(0.052)$ & $(0.104)$ & $(0.036)$ & $(0.024)$ \\
\hline \multirow[t]{2}{*}{$1 /$ Alfa } & 0.980 & 0.911 & 0.897 & 0.846 & 0.847 & 1.082 & 1.142 \\
\hline & $(0.046)$ & $(0.044)$ & $(0.052)$ & $(0.037)$ & $(0.074)$ & $(0.043)$ & $(0.031)$ \\
\hline
\end{tabular}

Note: Standard errors in parenthesis 


\section{Table 8}

\section{Argentina- Labour Mobility: Multinomial logit}

\begin{tabular}{|c|c|c|c|c|c|c|c|}
\hline & 1998-1999 & 1999-2000 & $2000-2001$ & 2001-2002 & $2002-2003$ & 2003-2004 & 2004-2005 \\
\hline Observations & 888 & 907 & 935 & 1,141 & 496 & 991 & 941 \\
\hline LR chi ${ }^{2}$ & 100.51 & 120.54 & 80.74 & 70.48 & 80.12 & 159.52 & 140.02 \\
\hline Prob $>$ chi $^{2}$ & 0.0000 & 0.0000 & 0.0000 & 0.0000 & 0.0000 & 0.0000 & 0.0000 \\
\hline \multirow[t]{2}{*}{ Pseudo R ${ }^{2}$} & 0.0604 & 0.0724 & 0.0500 & 0.0297 & 0.0973 & 0.0890 & 0.0867 \\
\hline & \multicolumn{7}{|c|}{ Unemployment to formal sector } \\
\hline \multirow[t]{2}{*}{ Complete primary } & -0.089 & 0.092 & -0.055 & -0.048 & 0.120 & -0.142 & 0.263 \\
\hline & $(0.055)$ & $(0.077)$ & $(0.042)$ & $(0.046)$ & $(0.112)$ & $(0.063)$ & $(0.095)^{*}$ \\
\hline \multirow[t]{2}{*}{ Incomplete secondary } & -0.071 & 0.116 & -0.089 & -0.052 & 0.171 & -0.280 & 0.215 \\
\hline & $(0.057)$ & $(0.077)$ & $(0.048)$ & $(0.048)$ & $(0.116)$ & $(0.064)^{* * *}$ & $(0.095)$ \\
\hline \multirow{2}{*}{ Complete secondary } & 0.000 & 0.174 & -0.017 & -0.070 & 0.035 & -0.044 & 0.317 \\
\hline & $(0.061)$ & $(0.078)$ & $(0.048)$ & $(0.052)$ & $(0.123)$ & $(0.060)$ & $(0.094)^{* *}$ \\
\hline \multirow[t]{2}{*}{ Incomplete Superior Ed. } & 0.162 & 0.258 & 0.121 & 0.039 & 0.242 & -0.061 & 0.358 \\
\hline & $(0.065)$ & $(0.079)^{* *}$ & $(0.052)$ & $(0.058)$ & $(0.119)$ & $(0.063)$ & $(0.097)^{* * *}$ \\
\hline \multirow[t]{2}{*}{ Complete Superior Ed. } & 0.131 & 0.380 & 0.229 & 0.113 & 0.445 & 0.060 & 0.703 \\
\hline & $(0.075)$ & $(0.088)^{* * *}$ & $(0.068)^{* *}$ & $(0.070)$ & $(0.137)^{* *}$ & $(0.079)$ & $(0.111)^{* * *}$ \\
\hline \multirow[t]{2}{*}{ Household head } & -0.033 & 0.057 & -0.023 & -0.013 & 0.033 & 0.059 & -0.087 \\
\hline & $(0.046)$ & $(0.040)$ & $(0.037)$ & $(0.038)$ & $(0.056)$ & $(0.046)$ & $(0.048)$ \\
\hline \multirow[t]{2}{*}{ Sex } & 0.156 & 0.119 & 0.055 & -0.064 & -0.019 & 0.071 & 0.007 \\
\hline & $(0.035)^{* * *}$ & $(0.032)^{* * *}$ & $(0.031)$ & $(0.030)$ & $(0.040)$ & $(0.031)$ & $(0.035)$ \\
\hline \multirow[t]{2}{*}{ Age 15 to 29} & 0.054 & 0.208 & -0.003 & 0.114 & 0.102 & 0.316 & 0.089 \\
\hline & $(0.054)$ & $(0.060)^{* *}$ & $(0.049)$ & $(0.047)$ & $(0.081)$ & $(0.073)^{* * *}$ & $(0.057)$ \\
\hline \multirow[t]{2}{*}{ Age 30 to 50} & -0.022 & 0.211 & -0.008 & 0.012 & 0.061 & 0.296 & 0.078 \\
\hline & $(0.048)$ & $(0.056) * * *$ & $(0.043)$ & $(0.045)$ & $(0.077)$ & $(0.071)^{* * *}$ & $(0.058)$ \\
\hline \multirow[t]{2}{*}{ Children } & 0.037 & -0.012 & 0.020 & 0.034 & -0.014 & -0.018 & 0.005 \\
\hline & $(0.013)^{*}$ & $(0.014)$ & $(0.010)$ & $(0.010)^{* *}$ & $(0.022)$ & $(0.016)$ & $(0.019)$ \\
\hline \multirow[t]{2}{*}{ GBA } & 0.020 & 0.040 & 0.035 & -0.070 & 0.022 & 0.053 & 0.053 \\
\hline & $(0.030)$ & $(0.030)$ & $(0.025)$ & $(0.027)^{*}$ & $(0.041)$ & $(0.029)$ & $(0.033)$ \\
\hline \multirow[t]{2}{*}{ Moderate poverty } & -0.086 & -0.018 & 0.001 & -0.005 & 0.029 & -0.109 & -0.026 \\
\hline & $(0.033)$ & $(0.032)$ & $(0.028)$ & $(0.030)$ & $(0.046)$ & $(0.030)^{* * *}$ & $(0.035)$ \\
\hline \multirow[t]{2}{*}{ Plan jefes(as) } & & & & & 0.097 & 0.485 & 0.372 \\
\hline & & & & & $(0.119)$ & $(0.085)^{* * *}$ & $(0.098)^{* * *}$ \\
\hline \multirow[t]{3}{*}{ Constant } & -0.174 & -0.536 & -0.173 & -0.053 & -0.370 & -0.251 & -0.397 \\
\hline & $(0.073)$ & $(0.092)^{* * *}$ & $(0.060)^{* *}$ & $(0.063)$ & $(0.127)^{* *}$ & $(0.091)^{*}$ & $(0.106)^{* * *}$ \\
\hline & & & \multicolumn{5}{|c|}{ From unemployment to informal sector } \\
\hline \multirow[t]{2}{*}{ Complete primary } & -0.045 & 0.043 & 0.009 & -0.058 & -0.132 & 0.092 & -0.204 \\
\hline & $(0.059)$ & $(0.064)$ & $(0.052)$ & $(0.048)$ & $(0.102)$ & $(0.071)$ & $(0.068)^{* *}$ \\
\hline \multirow[t]{2}{*}{ Incomplete secondary } & -0.054 & 0.031 & 0.071 & -0.086 & -0.047 & 0.213 & -0.152 \\
\hline & $(0.062)$ & $(0.066)$ & $(0.056)$ & $(0.051)$ & $(0.110)$ & $(0.071)^{* *}$ & $(0.067)$ \\
\hline \multirow[t]{2}{*}{ Complete secondary } & -0.150 & -0.136 & -0.032 & -0.048 & -0.319 & -0.021 & -0.202 \\
\hline & $(0.071)$ & $(0.070)$ & $(0.060)$ & $(0.055)$ & $(0.116)^{*}$ & $(0.073)$ & $(0.069)^{* *}$ \\
\hline \multirow[t]{2}{*}{ Incomplete Superior Ed. } & -0.353 & -0.270 & 0.033 & -0.145 & -0.160 & 0.006 & -0.320 \\
\hline & $(0.088)^{* * *}$ & $(0.078)^{* *}$ & $(0.069)$ & $(0.067)$ & $(0.123)$ & $(0.077)$ & $(0.077)^{* * *}$ \\
\hline \multirow[t]{2}{*}{ Complete Superior Ed. } & -0.403 & -0.516 & -0.540 & -0.213 & -0.752 & -0.302 & -0.664 \\
\hline & $(0.107)^{* * *}$ & $(0.121)^{* * *}$ & $(0.158)^{* *}$ & $(0.093)$ & $(0.229)^{* *}$ & $(0.118)$ & $(0.124)^{* * *}$ \\
\hline Household head & -0.025 & 0.034 & 0.161 & -0.090 & 0.076 & -0.002 & 0.156 \\
\hline
\end{tabular}




\begin{tabular}{|c|c|c|c|c|c|c|c|}
\hline & $(0.051)$ & $(0.045)$ & $(0.046) * * *$ & $(0.042)$ & $(0.071)$ & $(0.048)$ & $(0.045)^{* *}$ \\
\hline \multirow[t]{2}{*}{ Sex } & -0.028 & -0.075 & -0.038 & 0.054 & 0.068 & 0.056 & 0.025 \\
\hline & $(0.039)$ & $(0.037)$ & $(0.037)$ & $(0.035)$ & $(0.054)$ & $(0.034)$ & $(0.036)$ \\
\hline \multirow[t]{2}{*}{ Age 15 to 29} & -0.139 & -0.123 & 0.199 & -0.118 & -0.080 & -0.104 & -0.065 \\
\hline & $(0.060)$ & $(0.058)$ & $(0.060)^{* *}$ & $(0.049)$ & $(0.092)$ & $(0.061)$ & $(0.054)$ \\
\hline \multirow[t]{2}{*}{ Age 30 to 50} & -0.003 & -0.060 & 0.181 & 0.033 & -0.091 & -0.077 & -0.088 \\
\hline & $(0.053)$ & $(0.054)$ & $(0.053)^{* *}$ & $(0.044)$ & $(0.086)$ & $(0.059)$ & $(0.053)$ \\
\hline \multirow[t]{2}{*}{ Children } & -0.005 & 0.008 & 0.005 & -0.008 & 0.004 & 0.042 & 0.000 \\
\hline & $(0.015)$ & $(0.014)$ & $(0.012)$ & $(0.012)$ & $(0.026)$ & $(0.015)^{*}$ & $(0.017)$ \\
\hline \multirow[t]{2}{*}{ GBA } & -0.006 & -0.113 & 0.016 & 0.038 & 0.022 & -0.073 & -0.073 \\
\hline & $(0.035)$ & $(0.033)^{* *}$ & $(0.030)$ & $(0.029)$ & $(0.053)$ & $(0.031)$ & $(0.032)$ \\
\hline \multirow[t]{2}{*}{ Moderate poverty } & 0.088 & -0.086 & -0.021 & 0.006 & 0.090 & 0.035 & 0.107 \\
\hline & $(0.038)$ & $(0.035)$ & $(0.033)$ & $(0.033)$ & $(0.062)$ & $(0.035)$ & $(0.035)^{* *}$ \\
\hline \multirow[t]{2}{*}{ Plan jefes(as) } & & & & & -0.005 & -0.101 & -0.031 \\
\hline & & & & & $(0.140)$ & $(0.118)$ & $(0.101)$ \\
\hline \multirow[t]{2}{*}{ Constant } & 0.185 & 0.285 & -0.252 & 0.102 & 0.149 & -0.010 & 0.207 \\
\hline & $(0.084)$ & $(0.084)^{* *}$ & $(0.075)^{* *}$ & $(0.068)$ & $(0.131)$ & $(0.089)$ & $(0.083)$ \\
\hline
\end{tabular}

Note: Standard errors in parenthesis

Figure 4

Generalized Lorenz Curves
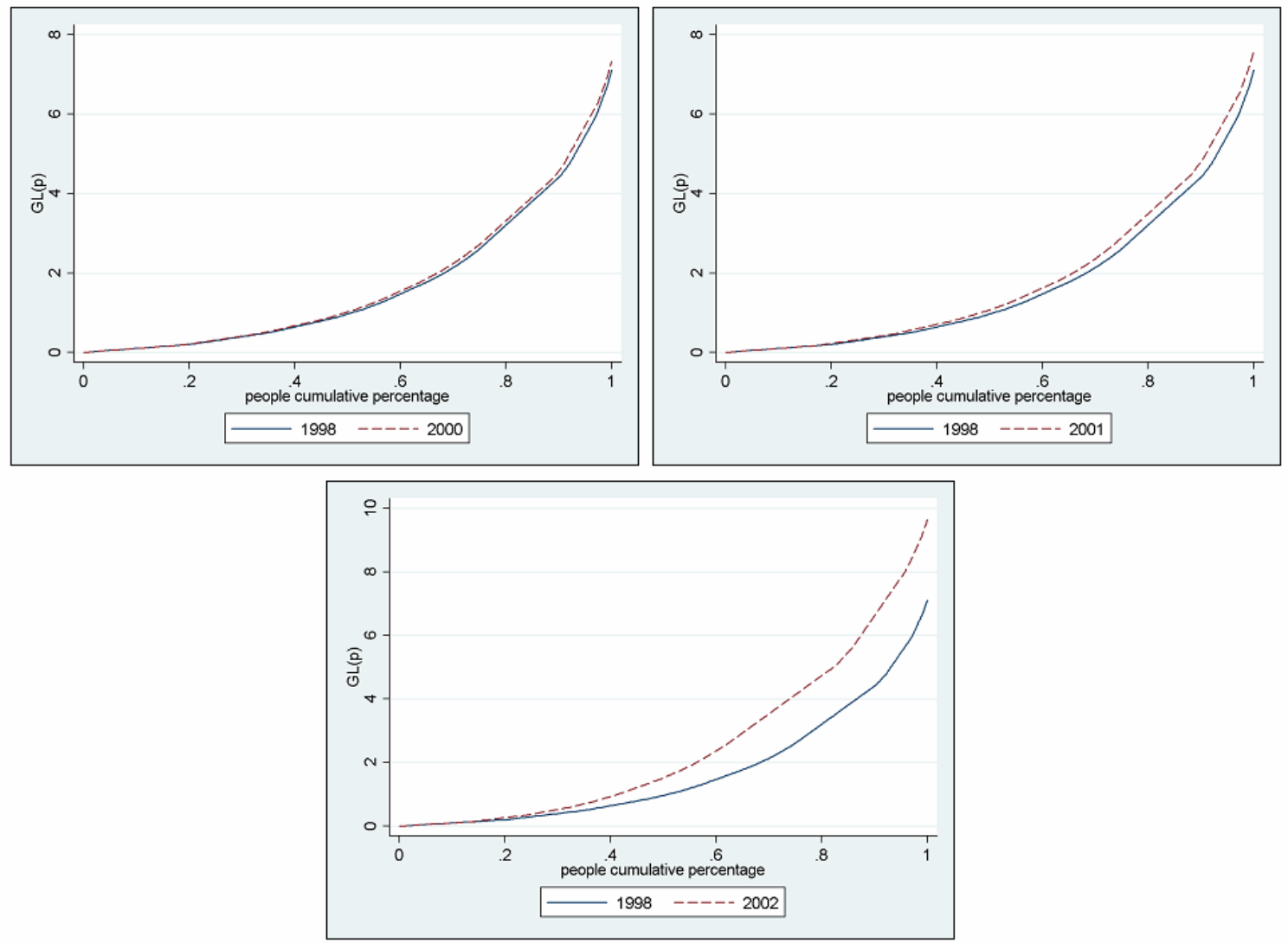

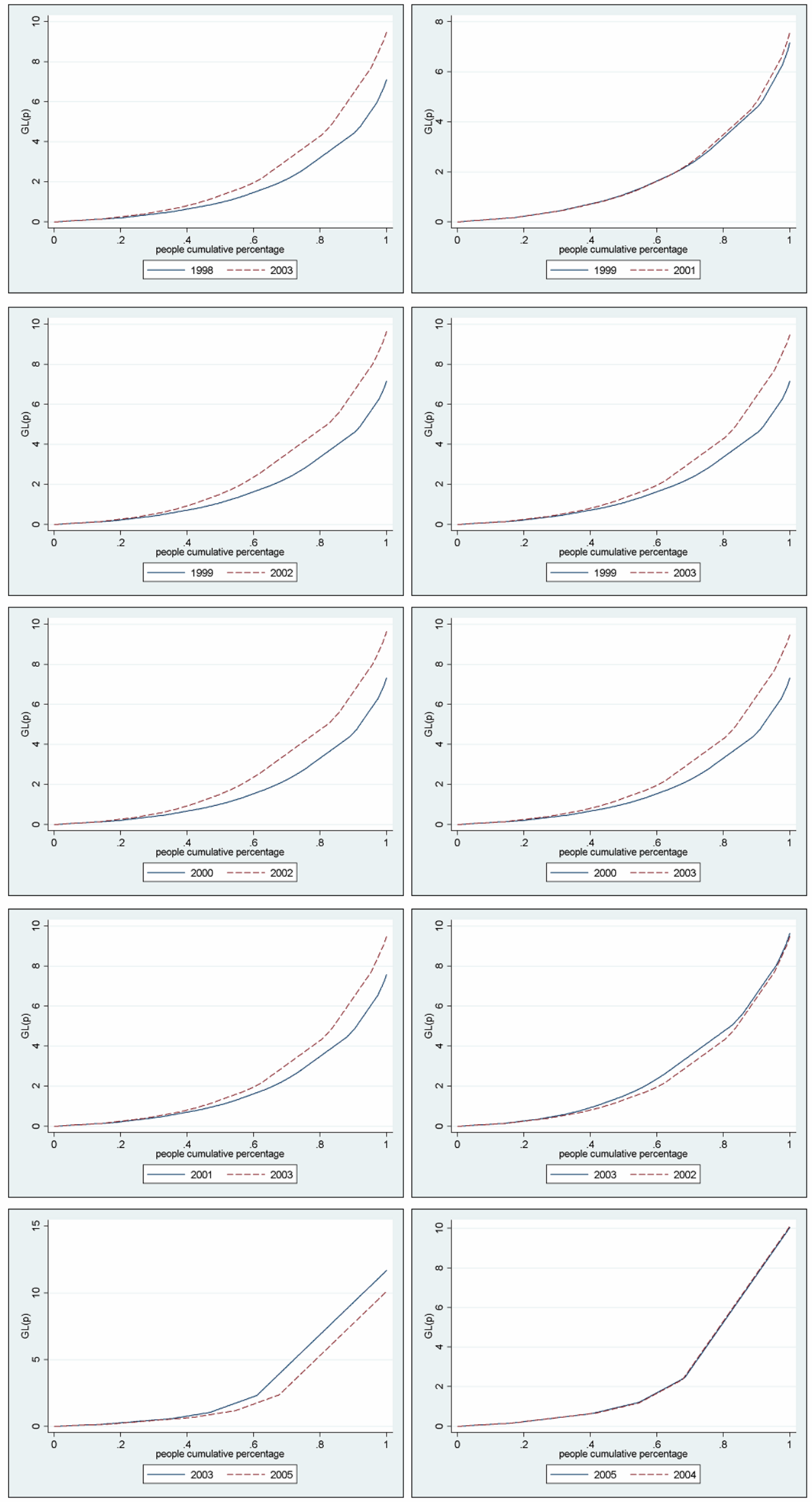
Table 9

Labour Mobility transition

Willingness to switch from initial sector to final sector(Vij)

\begin{tabular}{|c|c|c|c|c|}
\hline & \multirow[b]{2}{*}{ 1998-1999 } & \multicolumn{3}{|c|}{ Final sector } \\
\hline & & Formal & Informal & Unemployment \\
\hline \multirow{5}{*}{$\begin{array}{l}\text { Initial } \\
\text { sector }\end{array}$} & Formal & & 2,90 & 0,58 \\
\hline & Informal & 4,59 & & 0,79 \\
\hline & Unemployment & 2,30 & 2,89 & \\
\hline & & & Final sector & \\
\hline & 1999-2000 & Formal & Informal & Unemployment \\
\hline \multirow{5}{*}{$\begin{array}{l}\text { Initial } \\
\text { sector }\end{array}$} & Formal & & 2,71 & 0,67 \\
\hline & Informal & 3,68 & & 1,03 \\
\hline & Unemployment & 2,25 & 2,71 & \\
\hline & & & Final sector & \\
\hline & $2000-2001$ & Formal & Informal & Unemployment \\
\hline \multirow{5}{*}{$\begin{array}{l}\text { Initial } \\
\text { sector }\end{array}$} & Formal & & 2,21 & 1,01 \\
\hline & Informal & 3,31 & & 1,40 \\
\hline & Unemployment & 1,75 & 2,83 & \\
\hline & & & Final sector & \\
\hline & 2001-2002 & Formal & Informal & Unemployment \\
\hline \multirow{5}{*}{$\begin{array}{l}\text { Initial } \\
\text { sector }\end{array}$} & Formal & & 2,23 & 0,78 \\
\hline & Informal & 3,97 & & 1,04 \\
\hline & Unemployment & 2,21 & 2,44 & \\
\hline & & & Final sector & \\
\hline & $2002-2003$ & Formal & Informal & Unemployment \\
\hline \multirow{5}{*}{$\begin{array}{l}\text { Initial } \\
\text { sector }\end{array}$} & Formal & & 3,01 & 0,56 \\
\hline & Informal & 5,06 & & 0,71 \\
\hline & Unemployment & 2,01 & 3,29 & \\
\hline & & & Final sector & \\
\hline & 2003-2004 & Formal & Informal & Unemployment \\
\hline \multirow{5}{*}{$\begin{array}{l}\text { Initial } \\
\text { sector }\end{array}$} & Formal & & 3,22 & 0,43 \\
\hline & Informal & 5,29 & & 0,81 \\
\hline & Unemployment & 2,47 & 2,87 & \\
\hline & & & Final sector & \\
\hline & 2004-2005 & Formal & Informal & Unemployment \\
\hline \multirow{3}{*}{$\begin{array}{l}\text { Initial } \\
\text { sector }\end{array}$} & Formal & & 2,87 & 0,46 \\
\hline & Informal & 5,57 & & 0,60 \\
\hline & Unemployment & 2,70 & 2,40 & \\
\hline
\end{tabular}




\section{SERIE DOCUMENTOS DE TRABAJO DEL CEDLAS}

Todos los Documentos de Trabajo del CEDLAS están disponibles en formato electrónico en $<w w w$.depeco.econo.unlp.edu.ar/cedlas $>$.

- Nro. 55 (Julio, 2007). Leonardo Gasparini, Javier Alejo, Francisco Haimovich, Sergio Olivieri y Leopoldo Tornarolli. "Poverty among the Elderly in Latin America and the Caribbean".

- Nro. 54 (Julio, 2007). Gustavo Javier Canavire-Bacarreza y Luís Fernando Lima Soria. "Unemployment Duration and Labor Mobility in Argentina: A Socioeconomic-Based Pre- and Post-Crisis Analysis".

- Nro. 53 (Junio, 2007). Leonardo Gasparini, Francisco Haimovich y Sergio Olivieri. "Labor Informality Effects of a Poverty-Alleviation Program".

- Nro. 52 (Junio, 2007). Nicolás Epele y Victoria Dowbley. "Análisis Ex-Ante de un Aumento en la Dotación de Capital Humano: El Caso del Plan Familias de Transferencias Condicionadas".

- Nro. 51 (Mayo, 2007). Jerónimo Carballo y María Bongiorno. "Vulnerabilidad Individual: Evolución, Diferencias Regionales e Impacto de la Crisis. Argentina 1995 - 2005".

- Nro. 50 (Mayo, 2007). Paula Giovagnoli. "Failures in School Progression".

- Nro. 49 (Abril, 2007). Sebastian Galiani, Daniel Heymann, Carlos Dabús y Fernando Tohmé. "Land-Rich Economies, Education and Economic Development".

- Nro. 48 (Abril, 2007). Ricardo Bebczuk y Francisco Haimovich. "MDGs and Microcredit: An Empirical Evaluation for Latin American Countries".

- Nro. 47 (Marzo, 2007). Sebastian Galiani y Federico Weinschelbaum. "Modeling Informality Formally: Households and Firms".

- Nro. 46 (Febrero, 2007). Leonardo Gasparini y Leopoldo Tornarolli. "Labor Informality in Latin America and the Caribbean: Patterns and Trends from Household Survey Microdata".

- Nro. 45 (Enero, 2007). Georgina Pizzolitto. "Curvas de Engel de Alimentos, Preferencias Heterogéneas y Características Demográficas de los Hogares: Estimaciones para Argentina".

- Nro. 44 (Diciembre, 2006). Rafael Di Tella, Sebastian Galiani y Ernesto Schargrodsky. "Crime Distribution and Victim Behavior during a Crime Wave". 
- Nro. 43 (Noviembre, 2006). Martín Cicowiez, Leonardo Gasparini, Federico Gutiérrez y Leopoldo Tornarolli. "Areas Rurales y Objetivos de Desarrollo del Milenio en America Latina y El Caribe".

- Nro. 42 (Octubre, 2006). Martín Guzmán y Ezequiel Molina. "Desigualdad e Instituciones en una Dimensión Intertemporal".

- Nro. 41 (Septiembre, 2006). Leonardo Gasparini y Ezequiel Molina. "Income Distribution, Institutions and Conflicts: An Exploratory Analysis for Latin America and the Caribbean".

- Nro. 40 (Agosto, 2006). Leonardo Lucchetti. "Caracterización de la Percepción del Bienestar y Cálculo de la Línea de Pobreza Subjetiva en Argentina".

- Nro. 39 (Julio, 2006). Héctor Zacaria y Juan Ignacio Zoloa. "Desigualdad y Pobreza entre las Regiones Argentinas: Un Análisis de Microdescomposiciones".

- Nro. 38 (Julio, 2006). Leonardo Gasparini, Matías Horenstein y Sergio Olivieri. "Economic Polarisation in Latin America and the Caribbean: What do Household Surveys Tell Us?".

- $\quad$ Nro. 37 (Junio, 2006). Walter Sosa-Escudero, Mariana Marchionni y Omar Arias. "Sources of Income Persistence: Evidence from Rural El Salvador".

- Nro. 36 (Mayo, 2006). Javier Alejo. "Desigualdad Salarial en el Gran Buenos Aires: Una Aplicación de Regresión por Cuantiles en Microdescomposiciones".

- Nro. 35 (Abril, 2006). Jerónimo Carballo y María Bongiorno. "La Evolución de la Pobreza en Argentina: Crónica, Transitoria, Diferencias Regionales y Determinantes (1995-2003)".

- Nro. 34 (Marzo, 2006). Francisco Haimovich, Hernán Winkler y Leonardo Gasparini. "Distribución del Ingreso en América Latina: Explorando las Diferencias entre Países".

- Nro. 33 (Febrero, 2006). Nicolás Parlamento y Ernesto Salinardi. "Explicando los Cambios en la Desigualdad: Son Estadísticamente Significativas las Microsimulaciones? Una Aplicación para el Gran Buenos Aires".

- Nro. 32 (Enero, 2006). Rodrigo González. "Distribución de la Prima Salarial del Sector Público en Argentina".

- Nro. 31 (Enero, 2006). Luis Casanova. "Análisis estático y dinámico de la pobreza en Argentina: Evidencia Empírica para el Periodo 1998-2002".

- Nro. 30 (Diciembre, 2005). Leonardo Gasparini, Federico Gutiérrez y Leopoldo Tornarolli. "Growth and Income Poverty in Latin America and the Caribbean: Evidence from Household Surveys".

- Nro. 29 (Noviembre, 2005). Mariana Marchionni. "Labor Participation and Earnings for Young Women in Argentina". 
- $\quad$ Nro. 28 (Octubre, 2005). Martín Tetaz. "Educación y Mercado de Trabajo".

- Nro. 27 (Septiembre, 2005). Matías Busso, Martín Cicowiez y Leonardo Gasparini. "Ethnicity and the Millennium Development Goals in Latin America and the Caribbean".

- Nro. 26 (Agosto, 2005). Hernán Winkler. "Monitoring the Socio-Economic Conditions in Uruguay".

- Nro. 25 (Julio, 2005). Leonardo Gasparini, Federico Gutiérrez y Guido G. Porto. "Trade and Labor Outcomes in Latin America's Rural Areas: A Cross-Household Surveys Approach".

- Nro. 24 (Junio, 2005). Francisco Haimovich y Hernán Winkler. "Pobreza Rural y Urbana en Argentina: Un Análisis de Descomposiciones".

- Nro. 23 (Mayo, 2005). Leonardo Gasparini y Martín Cicowiez. "Equality of Opportunity and Optimal Cash and In-Kind Policies".

- Nro. 22 (Abril, 2005). Leonardo Gasparini y Santiago Pinto. "Equality of Opportunity and Optimal Cash and In-Kind Policies".

- Nro. 21 (Abril, 2005). Matías Busso, Federico Cerimedo y Martín Cicowiez. "Pobreza, Crecimiento y Desigualdad: Descifrando la Última Década en Argentina".

- Nro. 20 (Marzo, 2005). Georgina Pizzolitto. "Poverty and Inequality in Chile: Methodological Issues and a Literature Review".

- Nro. 19 (Marzo, 2005). Paula Giovagnoli, Georgina Pizzolitto y Julieta Trías. "Monitoring the Socio-Economic Conditions in Chile".

- Nro. 18 (Febrero, 2005). Leonardo Gasparini. "Assessing Benefit-Incidence Results Using Decompositions: The Case of Health Policy in Argentina".

- Nro. 17 (Enero, 2005). Leonardo Gasparini. "Protección Social y Empleo en América Latina: Estudio sobre la Base de Encuestas de Hogares".

- Nro. 16 (Diciembre, 2004). Evelyn Vezza. "Poder de Mercado en las Profesiones Autorreguladas: El Desempeño Médico en Argentina".

- Nro. 15 (Noviembre, 2004). Matías Horenstein y Sergio Olivieri. "Polarización del Ingreso en la Argentina: Teoría y Aplicación de la Polarización Pura del Ingreso".

- Nro. 14 (Octubre, 2004). Leonardo Gasparini y Walter Sosa Escudero. "Implicit Rents from Own-Housing and Income Distribution: Econometric Estimates for Greater Buenos Aires".

- Nro. 13 (Septiembre, 2004). Monserrat Bustelo. "Caracterización de los Cambios en la Desigualdad y la Pobreza en Argentina Haciendo Uso de Técnicas de Descomposiciones Microeconometricas (1992-2001)". 
- Nro. 12 (Agosto, 2004). Leonardo Gasparini, Martín Cicowiez, Federico Gutiérrez y Mariana Marchionni. "Simulating Income Distribution Changes in Bolivia: a Microeconometric Approach".

- Nro. 11 (Julio, 2004). Federico H. Gutierrez. "Dinámica Salarial y Ocupacional: Análisis de Panel para Argentina 1998-2002".

- Nro. 10 (Junio, 2004). María Victoria Fazio. "Incidencia de las Horas Trabajadas en el Rendimiento Académico de Estudiantes Universitarios Argentinos".

- Nro. 9 (Mayo, 2004). Julieta Trías. "Determinantes de la Utilización de los Servicios de Salud: El Caso de los Niños en la Argentina".

- Nro. 8 (Abril, 2004). Federico Cerimedo. "Duración del Desempleo y Ciclo Económico en la Argentina".

- Nro. 7 (Marzo, 2004). Monserrat Bustelo y Leonardo Lucchetti. "La Pobreza en Argentina: Perfil, Evolución y Determinantes Profundos (1996, 1998 Y 2001)".

- Nro. 6 (Febrero, 2004). Hernán Winkler. "Estructura de Edades de la Fuerza Laboral y Distribución del Ingreso: Un Análisis Empírico para la Argentina".

- Nro. 5 (Enero, 2004). Pablo Acosta y Leonardo Gasparini. "Capital Accumulation, Trade Liberalization and Rising Wage Inequality: The Case of Argentina".

- Nro. 4 (Diciembre, 2003). Mariana Marchionni y Leonardo Gasparini. "Tracing Out the Effects of Demographic Changes on the Income Distribution. The Case of Greater Buenos Aires".

- Nro. 3 (Noviembre, 2003). Martín Cicowiez. "Comercio y Desigualdad Salarial en Argentina: Un Enfoque de Equilibrio General Computado".

- Nro. 2 (Octubre, 2003). Leonardo Gasparini. "Income Inequality in Latin America and the Caribbean: Evidence from Household Surveys".

- Nro. 1 (Septiembre, 2003). Leonardo Gasparini. "Argentina's Distributional Failure: The Role of Integration and Public Policies". 